\title{
EFEITO DO TRATAMENTO TÉRMICO DO LEITE NA QUALIDADE DE IOGURTE
}

\author{
WILMA MARIA COELHO ARAÚJO
}

Dissertaçäo apresentada à Escola Suporior do Agricultura "Luiz de Queiroz", da Universidade de São Paulo, para obtençăo do título de Mestro em Agronomia - Área de Concentração: Tecnologia de Ali. mentos.

\author{
$P|R A C| C A B A$ \\ Estado de São Paulo Brasil \\ Marco, 1984
}


A meus pais

\section{VICENTE (in memoriam) e. RENELDE}

A ADEMIR, companheiro,

$e$ aos nossos filhos

VICENTE A ADEMIR 


\section{AGRADECIMENTOS}

Ao Prof. Dr. Joào Gustavo Brasil Caruso, pela segura orientação e mütua amizade construĩda na realização deste tra baltho.

Ao Prof. Dr. Antōnio Joaquim de oliveira, pelas sugestões apresentadas e pelo marcante incentivo de amigo.

A Profa. Dra. Nonete Barbosa Guerra, Coordenadora do Laboratōrio de Experimentação e Anālises de Alimentos do Departamento de Nutrição da Universiade Federal de Pernam buco, pelo total apoio recebido.

Profa. Edleide Maria Freitas Pires, pela aplicação da anā i ise sensorial.

Aos professores e aos colegas do Curso de Pös-Graduação em Tecnologia de Alimentos (1980/1981) da Escola Superior de Agricultura "Luiz de Queiroz", pelo convívio saudável e pela motivação conjunta.

Aos funcionārios do Departamento de Tecnologia Rural da Esco la Superior de Agricultura "Luiz de Queiroz", e aos funcionārios do Laboratōrio de Experimentação e Anālises de Alimentos, pelos valiosos auxilios prestados.

Coordenadoria de Aperfeiçoamento de Pessoal do Ensino Sü perior (CAPES), pelo auxîlio concedido a partir de 1980 , na forma de bolsa de estudos, e ao Departamento de Nutri ção da Universidade Federal de Pernambuco, pelos recur sos oferecidos. 


\section{INDICE}

pàgina

LISTA DE TABELAS $\ldots \ldots \ldots \ldots \ldots \ldots \ldots \ldots \ldots \ldots \ldots \ldots$

LISTA DE FIGURAS $\ldots \ldots \ldots \ldots \ldots \ldots \ldots \ldots \ldots \ldots \ldots \ldots \ldots \ldots \ldots \ldots$

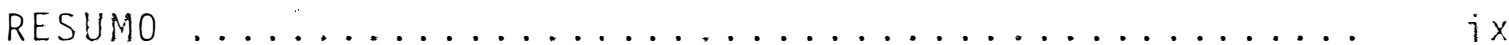

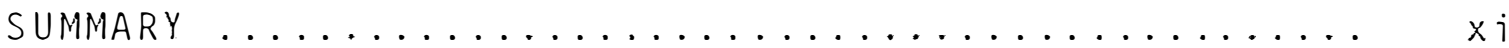

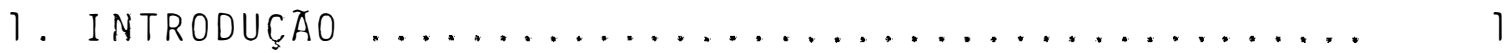

2. REVISAOO DE LITERATURA .................. 4

2.1. Matéria-prima ................... 4

2.2. Cultura lätica ..................... 7

2.3. Processamento ...................... 1]

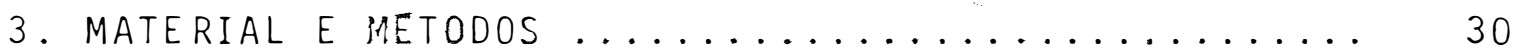

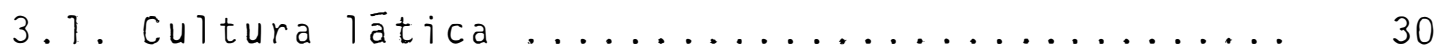

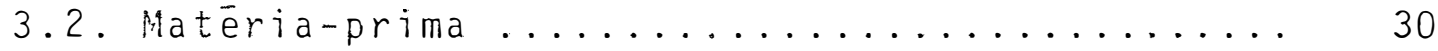

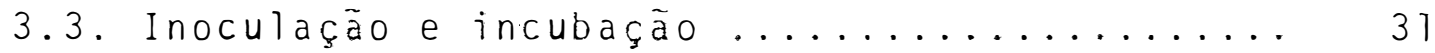

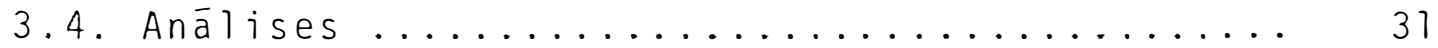

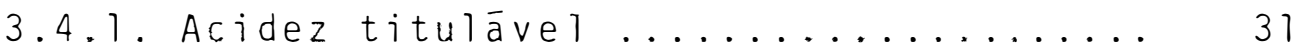

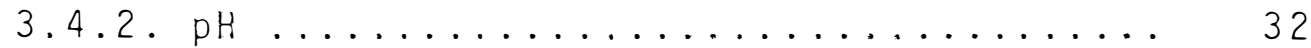

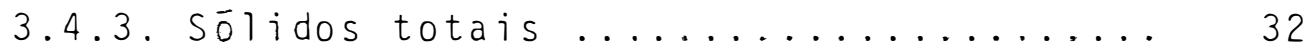

3.4.4. Contagem de microrganismos ......... 33

3.4 .5 . Anālise sensorial ............... 33

4. RESULTADOS E DISCUSSAO .................. 37

4.1. Caracteristicas principais da matēria-prima . 37 
Pàgina

4.2. Acidez titulável e pH ................... 38

4.3. Crescimento microbiano .............. 46

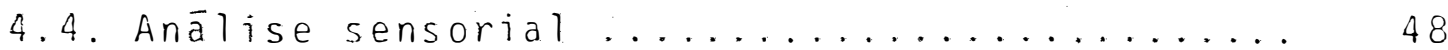

4.5. Conservação do iogurte sob refrigeração .... 51

5. CONCLUSOES ............................ 54

6. LITERATURA CITADA $\ldots \ldots \ldots \ldots \ldots \ldots \ldots \ldots \ldots \ldots \ldots \ldots$

7. APENDICE ............................. 70 


\section{LISTA DE TABELAS}

Tabeia No

Pāgina

1 - Efeitos físicos e químicos do tratamento térmi

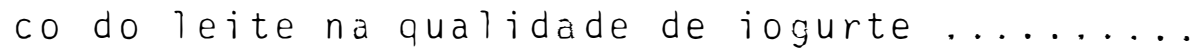

2 - Efeito do tratamento térmico nas proteinas do

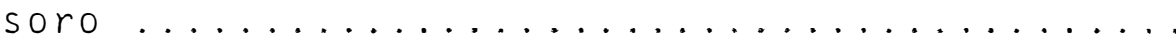

3 - Efeito do tratamento térmico no processo decoa

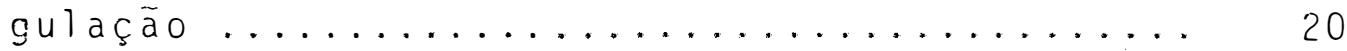

4 - Caracteristicas principais do leite antes e apōs o tratamento térmico a 650 C por 30 minu -

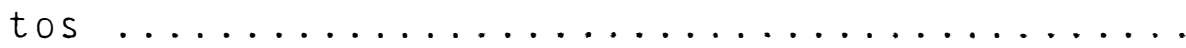

5 - Características principais do leite antes e apōs o tratamento térmico a $750 \mathrm{c}$ por 10,20 e

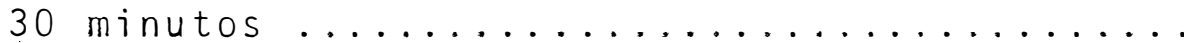

6 - Características principais do leite antes e apōs o tratamento térmico a 85 oc por 10, 20 e

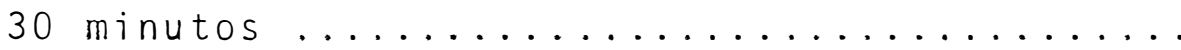

7 - pH e acidez titulàvel durante a fermentação do leite previamente aquecido a $650 \mathrm{C}$ por 30 minutos. Temperatura de incubação $4200 \ldots . . . .$.

8 - pH e acidez titulāvel durante a fermentação do leite previamente aquecido a $750 \mathrm{c}$ por 10,20 e 30 minutos. Temperatura de incubação $42 ! C \ldots$. 
9 - pH e acidez titulável durante a fermentação do leite previamente aquecido a $850 \mathrm{C}$ por 10,20 e 30 minutos. Temperatura de incubação $420 \mathrm{C} . .$.

10 - pH e acidez titulāvel durante a fermentação do leite previamente aquecido a $750 \mathrm{C}$ por 30 minutos. Temperaturas de incubação 320 C e 370 C...

11 - pH e acidez titulável durante a fermentação do leite previamente aquecido a $850 \mathrm{C}$ por 30 minutos. Temperaturas de incubação $320 \mathrm{C}$ e $370 \mathrm{C} \ldots$

12 - Anālise sensorial dos iogurtes obtidos de leite aquecido a 850 C por 10,20 e 30 minutos...

13 - Anālise sensorial dos iogurtes obtidos de leite aquecido a $75 \subseteq \mathrm{C}$ por 10,20 e 30 minutos ...

14 - Anālise sensorial dos iogurtes obtidos de leite aquecido a $650 \mathrm{C}, 750 \mathrm{C}$ e $850 \mathrm{C}$ por 30 minutos

15 - pH e acidez titulàvel durante o armazenamento, para os tratamentos térmicos $750 \mathrm{C}$ e $850 \mathrm{C}$ por

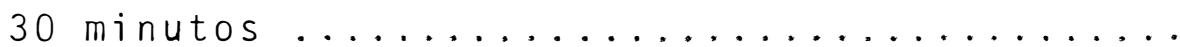




\section{LISTA DE FIGURAS}

Figura No

Pàgina

1 - Modelo da ficha utilizada na avaliação senso rial, para o teste de preferéncia .......... 34

2 - Modelo da ficha utilizada na avaliação senso-

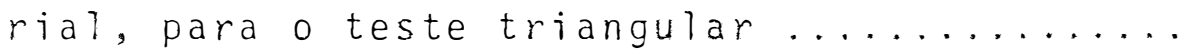




\title{
EFEITO DO TRATAMENTO TERMICO DO LEITE \\ NA QUALIDADE DE IOGURTE
}

\author{
Candidata: WILMA MARIA COELHO ARAOJO \\ Orientador: JOAO GUSTAVO BRASIL CARUSO
}

\section{RESUMO}

0 efeito do tratamento térmico do leite na qua lidade do iogurte foi investigado aquecendo-se o leite em banho-maria a 650 por $30 \mathrm{~min}$, $750 \mathrm{C}$ por 10,20 e $30 \mathrm{~min}$. e 850 C por 10,20 e 30 min.

Após cada tratamento térmico, o leite era inoculado com 3,0\% de uma cultura lática para iogurte (Streptococcus thermophilus e Lactobacilkus bulgaricus) e incubado a 32,37 e 420 c respectivamente, até completa coagulação.

Durante o perīodo de incubação (fermentação), foram retiradas amostras a intervalos regulares de 20 minutos para determinação do pH e da acidez titulável e contagem de microrganismos pela técnica da contagem em placa.

A qualidade do iogurte foi avaliada por um pa $\underline{i}$ nel de dez degustadores, utilizando-se a escala hedónica e o teste triangular para diferenciar a qualidade do produto fei- 
to com o leite tratado como foi acima descrito. Aos degustadores foi pedido julgarem o flavor e a consisténcia do produto.

$$
\text { A anāilise estatistica dos resultados mostrou }
$$

uma preferência significativa pelo produto feito com o leite tratado a 850 C por 30 minutos. Contudo, após dez dias de armazenagem a 30 C, a preferēncia foi para o iogurte feito com leite aquecido a 750 C por 30 minutos, embora a diferença entre os produtos não tenha sido significativa. 


\title{
THE HILX HEAT TREATMENT EFFECT \\ DN THE YOGURT QUALITY
}

\author{
Candidate: WILMA MARIA COELHO ARAOJO \\ Adviser: JOAO GUSTAVO BRASIL CARUSO
}

\section{SUMHARY}

The effect of the milk heat treatment on the yogurt quality was investigated by heating the milk in water bath at $650 \mathrm{C}$ for $30 \mathrm{~min}, 750 \mathrm{C}$ for 10,20 and $30 \mathrm{~min}$. and $850 \mathrm{C}$ for 10,20 and $30 \mathrm{~min}$.

After each heat treatment the milk was innoculated with $3.0 \%$ of a yogurt starter (Streptococcus thermophilus and Lactobacillus bulgaricus) and incubated at 32,37 and 420 C respectively, until complete coagulation.

During the incubation period (fermentation) samples were taken at regular 20 minutes intervals for pH and titrable acidity determination and microbial population counting by plate count tecnic.

The yogurt quality was evaluated by a trained painel of ten panelists, using a hedonic scale from 0 to 6 and a triangle test to diferenciate the quality of the product made from milk heat treated as above described. To the panelists were asked to judge flavor and consistance of the product. 
The statistical analysis of the results show a significative preference for the product made from the milk heat treated at $850 \mathrm{C}$ for $30 \mathrm{~min}$. However, after ten days of storage at 30C, preference was for the yogurt made from the milk heated at $750 \mathrm{C}$ for $30 \mathrm{~min}$. although the difference between the products was not statistically significative. 


\section{INTRODUÇAOO}

A qualidade dos produtos alimentícios e a sua influéncia sobre a nutrição e a saūde humana vêm merecendo lu gar de destaque nos meios científicos. Essa preocupação se de ve ao grande número de produtos alimentícios existentes e a uma tendencia atual de se ingerir produtos naturais.

Dentre esses produtos destaca-se o iogurte, que é resultante da fermentação do açūcar do leite - a lactose por bactérias làticas.

Inicialmente, o consumo de iogurte foi bastante limitado, restringindo-se apenas a certos grupos étnicos. Em meados de 1960, a adição de frutas ao produto, com o objetivo de atenuar o seu sabor ácido, buscava uma maior aceitação popular, e, ao mesmo tempo, uma maior divulgação era dada às suas qualidades nutritivas e terapéuticas, levando a um considerável aumento no consumo do iogurte.

o valor nutritivo do iogurte é equivalente ao do leite utilizado em seu preparo, acrescido das vantagens 
advindas do processo de fermentação, tal como a presença de nutrientes resultantes da atividade das bactérias envolvidas nesse processo. De acordo com DOAN e DIZIKES (1942), o iogurte é mais digestivo que o leite, qualidade essa atribuída às mudanças químicas das proteinas durante a formação do produto, e, ainda, ele contribui para a metabolização de outros pro dutos devido à sua atividade diastásica.

0 iogurte, além da habilidade de restaurar a flora intestinal normal, no que diz respeito às bactérias do ácido lätico, inibe o crescimento de microrganismos proteoliti cos indesejāveis e é, também, uma opção aos indivĩduos que apresentam intolerāncia à lactose. KILARA e SHAHANI (1978) cha mam a atenção para uma ação inibitōria do iogurte contra certos tipos de células cancerígenas, contribuindo, assim, na te rapia de tumores malignos.

A elaboração do iogurte é uma técnica que se expande cada vez mais no mundo inteiro, e, de um preparo originalmente simples, vem-se transformando em um processo bastante sofisticado. Entretanto, com a rápida incorporação deste produto aos hábitos alimentares, a competição industrialde sencadeou a busca de novos processos que possibilitassem a re dução dos custos de fabricação, sem prejuízo da qualidade do produto.

Esse atributo é uma conseqüència, além das con dições de fabricação, da qualidade e do tratamento térmico do 
leite, como também da cultura lática empregada, uma vez que da sua açäo sobre os componentes do leite é que resultaräo as caracteristicas desejäveis no produto.

$$
\text { Tendo em vista esses fatos é que o presentetra }
$$
balho foi desenvolvido, com o principal objetivo de se observar possiveis efeitos sobre a qualidade do iogurte, resultantes de variações no tratamento tērmico do leite utilizado em seu preparo. 


\section{REYISAO DE LITERATURA}

\subsection{Matéria-prima}

A matēria-prima utilizada na elaboração do iogurte e o leite, principalmente o de origem bovina. Esse leite deve ser de excelente qualidade e sofrer tratamento adequa do para obtenção de um produto com as melhores características possiveis.

De acordo com BEHMER (1978), o reite é uma emul são de glóbulos graxos, estabilizada por substâncias albumi nóides em um soro que contēm em solução um açūcar (lactose), proteínas, sais orgānicos e minerais e vārios outros produtos, em quantidades minimas, tais como a lecitina, uréia, ami noàcidos, àcidos cîtrico, lātico e acético, vitaminas, enzimas, etc.

o leite destinado à elaboração do iogurte deve apresentar certas caracteristicas fundamentais, tais como as citadas por KURMANN (1977): auséncia total, ou presença mîni- 
má, de substäncias estranhas quantidade tecnicamente inevitä vel durante a produçào leiteira); auséncia de organismos patogênicos; ser isento de antibióticos; acidez máxima de 20 2400; apresentar sabor e odor normais; extrato seco o maisele vado possivel e ser proveniente de überes näo infectados.

O teor de sólidos totais do leite pode variar dentro da faixa de 10.5-16.0\% (FREITAS, 1971) e, para a ela boração do iogurte, os valores recomendados, segundo ROBINSON e TARIME (1975), situam-se entre 14 e $18 \%$. Esse teor de sölidos totais é de importāncia significativa, podendo, inclusi ve, exercer um controle no flavor e no aroma, na estabilidade e no valor nutritivo do iogurte (HUMPHREY, 7969).

No que diz respeito à acidez do leite, esta de ve apresentar valores normais, isto é, dentro da faixa de 0.14 a $0.20 \%$ (gramas de àcido lático por $100 \mathrm{ml}$ de leite). A determinação do pH é outra possibilidade de avaliação da acidez do leite que, recém-ordenhado, deve apresentar valores em torno de $6.5-6.7$ (SPREER, 1975).

GALESLOOT (1958), ASHTON (1963) e SIEGENTHALER e RITTER (1964a) mostraram a importāncia da gordura em relação ao flavor e à consistēncia do iogurte. Além do mais, o co nhecimento da sua concentração torna-se, às vezes, necessārio, uma vez que o iogurte pode ser classificado em trés possíveis tipos, conforme ele contenha teores de gordura elevado, médio ou baixo (FAO/WHO, 1973).

E de suma importáncia que o leite destinado à 
fabricaça do iogurte seja isento de antibioticos e esse ponto é relevante sob dois aspectos: primeiramente, porque peque nas concentrações podem afetar a atividade da cultura, legando ao produto uma qualidade inferior para o consumo, sem levar em consideração as perdas econōmicas no processamento; em segundo lugar, os residuos de antibioticos acarretam sérios problemas em termos de saúde püblica. Infelizmente, não existe um teste rāpido e eficiente para deteção de antibióticos no leite e assim definir a aceitação ou rejeição da matéria prima. Uma alternativa encontrada pela "The Milk Marketing Eoards", no Reino Unido, foi a de um sistema de multas paraos fornecedores que apresentassem o leite com uma concentração de antibióticos acima de 0.02 U.I./ml. Entretanto, esse valor não era välido para penicilina, pois a esses níveis ela não afeta a atividade das culturas iáticas.

Quanto à presença de substāncias inibidoras no leite, este contém duas classes de substáncias naturais que inibem o crescimento das culturas läticas: os anticorpos aglu tinantes específicos (aglutininas) e o sistema lacto-peroxida se-tiocianato- $\mathrm{H}_{2} \mathrm{O}_{2}$. As aglutininas são de importáncia secundäria, já que são inativadas pela homogeneização e pelo tratamento tērmico do leite. O sistema lacto-peroxidase-tiociana to- $\mathrm{H}_{2} \mathrm{O}_{2}$, porém, não apresenta efeitos inibidores a todas as linhagens de estreptococos do Grupo $N$, sendo que algumas são, inclusive, estimuladas (IARTINS, 1981).

Dentre os outros defeitos que o leite pode apre 
sentar, quando considerado como matéria-prima para a elaboraçăo do jogurte, destaca-se a rancidez. Certos àcídos graxos livres como o caprịico, o cāprico e o lāurico (COTISLOW e SPECK, 1951) säo inibidores no desenvolvimento da cultura lática (SIEGENTHALER e RITTER, 1964a). Outro defeito è o leite obtido de vacas com mastite, o qual, segundo KISZA e ROTKIEWICZ (1967), torna mais Tenta a atividade da cultura lática.

\subsection{Cultura làtica}

Para um perfeito controle de qualidade do processamento do iogurte é necessārio que se dè um destaque espe cial à cultura a ser utilizada, porque da sua açăo sobre os componentes do leite $\vec{e}$ que resultarão as características dese jāveis no produto final.

De acordo com SELLARS e BABEL (1970), as culturas läticas podem ser agrupadas em quatro diferentes catego rias: a) cultura simples, com uma única linhagem de Strepto coccus lactis ou de Streptacoccus cremoris; b) cultura tipo mista, que apresenta duas ou mais linhagens de uma mesma espécie; c) cultura tipo mültiplá, constituída por uma linhagem de Streptococcus lactis ou streptococcus cremoris, mais uma linhagem fermentadora de àcido çtrico; d) cultura tipo müttipla, que contém linhagens misturadas (produtoras de àci- 
do juntamente com fermentadoras de ácido cittrico). As caracte risticas de cada categoria é que influenciarão na escolna da cultura a ser utilizada.

Normalmente, as culturas láticas empregadas co mercialmente são compostas or bactérias produtoras de àcido lätico e fermentadoras de àcido cîtrico.

Para a seleção das culturas de iogurte, tendose em vista a segurança de uma boa fabricação e obtenção de um iogurte com elevada qualidade organoléptica, KURMANN(1977) cita certas características importantes a serem observadas na cultura:

a) poder acidificante - as culturas läticas de vem produzir uma acidez de $78-9090$ (0.78 a 0.90 g de ācido lático por $700 \mathrm{ml}$ do produto). Atualmente, existe uma tendēncia em se obter culturas com poder acidificante médio ou baixo, evitando-se assim a pōs-acidificação durante o resfriamen to, a estocagem e a distribuição do iogurte;

b) pōs-acidificaçäo - é a acidez produzida apōs. o período de incubação. Para produzir um iogurte doce e aromá tico é necessārio escolher culturas com a pōs - acidificaçăo mais baixa possivel;

c) formação de aroma - a cultura lātica deve conferir qualidades ao produto que sejam atrativas ao consumi dor. Os lactobacilos produzem aldeído acético, que confere o aroma típico do iogurte, enquanto os estreptococos, pelo menos algumas cepas, tēm capacidade de produzir diacetil (subs- 
táncio aromätica da manteiga), que pode ser um complemento util A formaçäo de substancias aromáticas pode ser despreza da para a fabricação de iogurte com frutas, mas é indispensàvel para a fabricação de iogurte natural;

d) formação de mucus - a produção de mucus meThora a viscosidade e a consisténcia do iogurte;

e) proteólise - a atividade proteolitica é de grande importāncia na elaboração do iogurte, pelas seguintes razoes: quando é intensa pode provocar enfraquecimento da es trutura, favorece a simbiose entre as culturas e, tambēm, poderá provocar o aparecimento do defeito chamado "amargo", devido ao acúmulo de peptídios.

As culturas láticas podem ser encontradas comercialmente nas formas liquida, liofilizada ou congelada (CA RINI, 1972; SPEECK, 1977, LLOYD, 1971 ; SELLARS, 1970).

A utilização da forma lìquida é viāvel quando em pequenas distáncias e sob a forma de leite inoculado, trans. portado sob refrigeração. O tempo de preservação, nestas condições, é de uma semana, sem implicações sērias em seu desempenho. Por outro lado, a forma liofilizada, no mercado nacio nal, é a forma física de distribuição mais comumente encontra da. O seu processamento envolve o congelamento da cultura, com posterior remoção de umidade sob alto vácuo, isto é, por sublimaçäo; é normal, neste caso, um certo grau de dano às célutas, que pode ser tanto menor quanto melhor a técnica utiti zada pelo laboratório produtor. Entretanto, para melhor 
aproveitamento, devem ser armazenadas sob refrigeração ou, de preferéncia, a temperaturas inferiores a $-230 \mathrm{C}$ (MARTINS, 1981). Conforme VIEIRA (1981), para que as culturas läticas apresentem boa viabilidade, apōs longo perīodo de tem po, elas devem ser armazenadas sob refrigeração, liofilizadas fora do meio de crescimento, a fim de que a presença de metabōlitos e, principalmente, o baixo pH, não as prejudiquem, ou então, liofilizadas em presença de agentes protetores, sendo os melhores o glutamato de sódio e o glicerol.

As culturas congeladas foram introduzidas no mercado internacional hà pouco mais de dez anos. São constituĩdas por suspensão concentrada de bactérias congeladas e mantidas em nitrogēnio líquido ou diōxido de carbono sōlido, e assim as cēlulas são mantidas em estado latente e seus processos enzímicos são total e temporariamente sustados. A gran de dificuldade existente para sua utilização no Brasil é o so fisticado sistema de distribuição e manutenção exigido, que dificulta seu transporte às fäbricas pequenas e isoladas (DUTTA, 1972).

As culturas làticas são vulnerāveis ao ataque de bacteriōfagos, que podem resultar em falhas na produção de àcido lático. Os fagos são eliminados por aquecimento a $850 \mathrm{C}$ /20 minutos (STOLK, 1955), e, uma vez que o tratamento térmico do leite para a produção do iogurte garante a destruição dos vĩrus, estes serão destruídos se forem originārios da matêria-prima. 
2.3. Processamento

No processamento do iogurte, uma matéria-prima de excelente qualidade e seu tratamento adequado säo pontos que merecem destaque especial.

o nivel de sölidos totais no leite é significante, e esta concentraçăo varia bastante, desde $9 \%$, para iogurte desnatado, até $20 \%$, em outros tipos de iogurte. ROBINSON e TAMIME (1976) mostraram que o valor recomendado situava - se entre 14-18\%. Entretanto, comercialmente, estas concen traçöes variam consideravelmente, sendo a faixa usual de 14 $15 \%$

Concentrações acima de $30 \%$ foram sugeridas por vārios pesquisadores (DORDEVIC et al., 1973; ZMARLICKI et al., 1974). Entretanto, um estudo realizado por PULAY e KRASZ (1974) acerca do efeito destas concentrações sobre a atividade da cultura concluiu que valores acima de $25 \%$ afetam adversamente o aproveitamento da matéria-prima e impedem a atividade dacul tura.

Além do mais, a concentração elevada de sōlidos afeta a acidez titulāvel, devido ao poder-tampäo das pro teinas, fosfatos, citratos, lactatos e outros constituintes (JENNESS E PATTON, 1959).

0 aumento dos sōlidos aumenta também a acidez titulävel (HUMPHREYS e PLUNKETT, 1969) e a reduçäo do tempo de coagulação. 
De acordo com DAVIS (1973), quando a concentra ção de sōitidos é duplicada, a acidez titulável também é duplicada.

A prática comum da adição do leite em pó (integral, desnatado ou semidesnatado) é amplamente usa da na indústria, com o objetivo de alcançar a concentração de sōlidos desejāvel. O nível de adição varia desde $7 \%$ (STOCKLIN, 1969; WILCOX, 1971; GROZDOVA, 1971) a 6\% (HAMMOND, 1972). Entretanto, o nīvel recomendado é o de $3-4 \%$, conforme BECKER (1971); STADHOUDERS e HASSING (1974) e DAVIS (1967, 1971 e $1973)$

A utilização de leite em pō é tambēm importante sob o ponto de vista de enriquecimento em vitaminas, parti rallarmente àcido ascórbico e vitamina B/2. SULC (1960a) mostrou que $84 \%$ de ácido ascōrbico são perdidos na concentração bite, enquanto RASIC e PANIC (1961, 1963) mostraram que a prafla de vitamina $B_{12}$, devido a a quecimento do leite, era de $5 .-70 \%$

outro procedimento utilizado para aumentar os niveis de sölidos é a concentração da mistura básica (ANON, 1976 a, 1977a; LUNDSTEDT, 1974 ; NIELSEN, 1974 ; BAUSTIAN, 1970), e é conduzida antes da homogeneização e do tratamento térmico. o processo normalmente ocorre por evaporação, e, com uma pequena perda de componentes voláteis, todos os constituintes do leite são retidos e concentrados. 
A evaporaça me Thora a consisténcia e reduz o flavor "goaty" do produto (HADLAND e HOFFMANN, 1974). A evapo raçào a vácuo também reduz a entrada de ar na mistura bàsica, diminuindo também a sinérese, aumentando a estabilidade do leite fermentado durante o armazenamento (GRADHAGE e THURELL, $1978)$.

Em termos de tratamento térmico, as pesquisas realizadas por STORGARDS (1964) relatam o efeito benéfico da pasteurização do leite sob dois aspectos: como melhoramentodo meio para o crescimento da cultura, com a conseqüente redução da população bacteriana e a formação de substāncias que atuam como estimulantes do crescimento da cultura; e também como me Thora de consistência e firmeza do iogurte.

Conforme relatou KURMANN (1977), através d. 0 aquecimento do leite é que se processa a desnaturação de uma quantidade elevada de proteínas do soro, que serão precipitadas durante a acidificação. Elas se inflam, absorvendo ägua, o que explica o melhoramento da consisténcia e da viscosida de.

Industrialmente, o leite destinado à fabricação do iogurte é pré-aquecido a 850 C por 30 minutos ou 90 950 C por 5-10 minutos.

Um resumo dos efeitos do tratamento térmico do leite e a relevāncia destes na manufatura do iogurte é dado na Tabela 1 . 


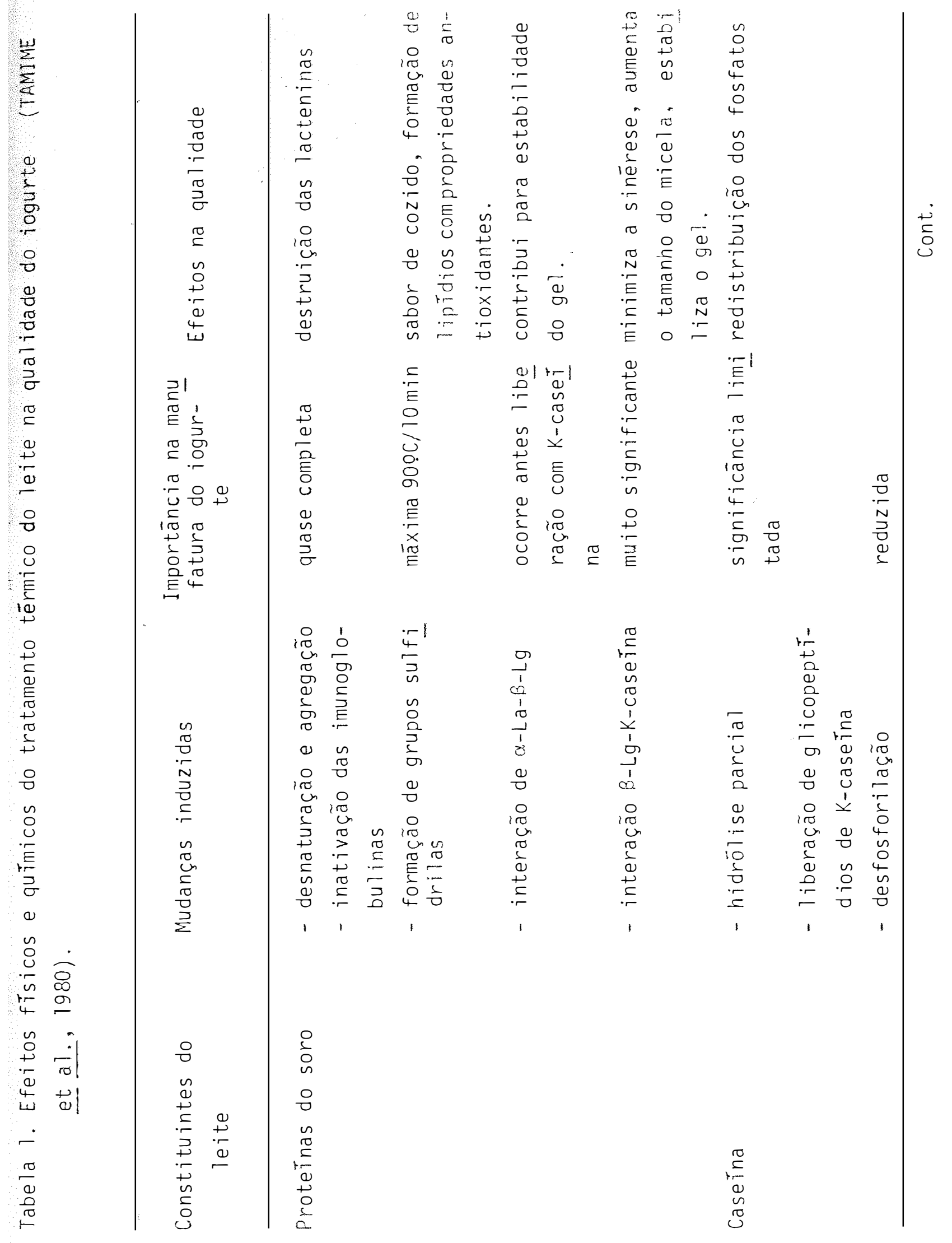




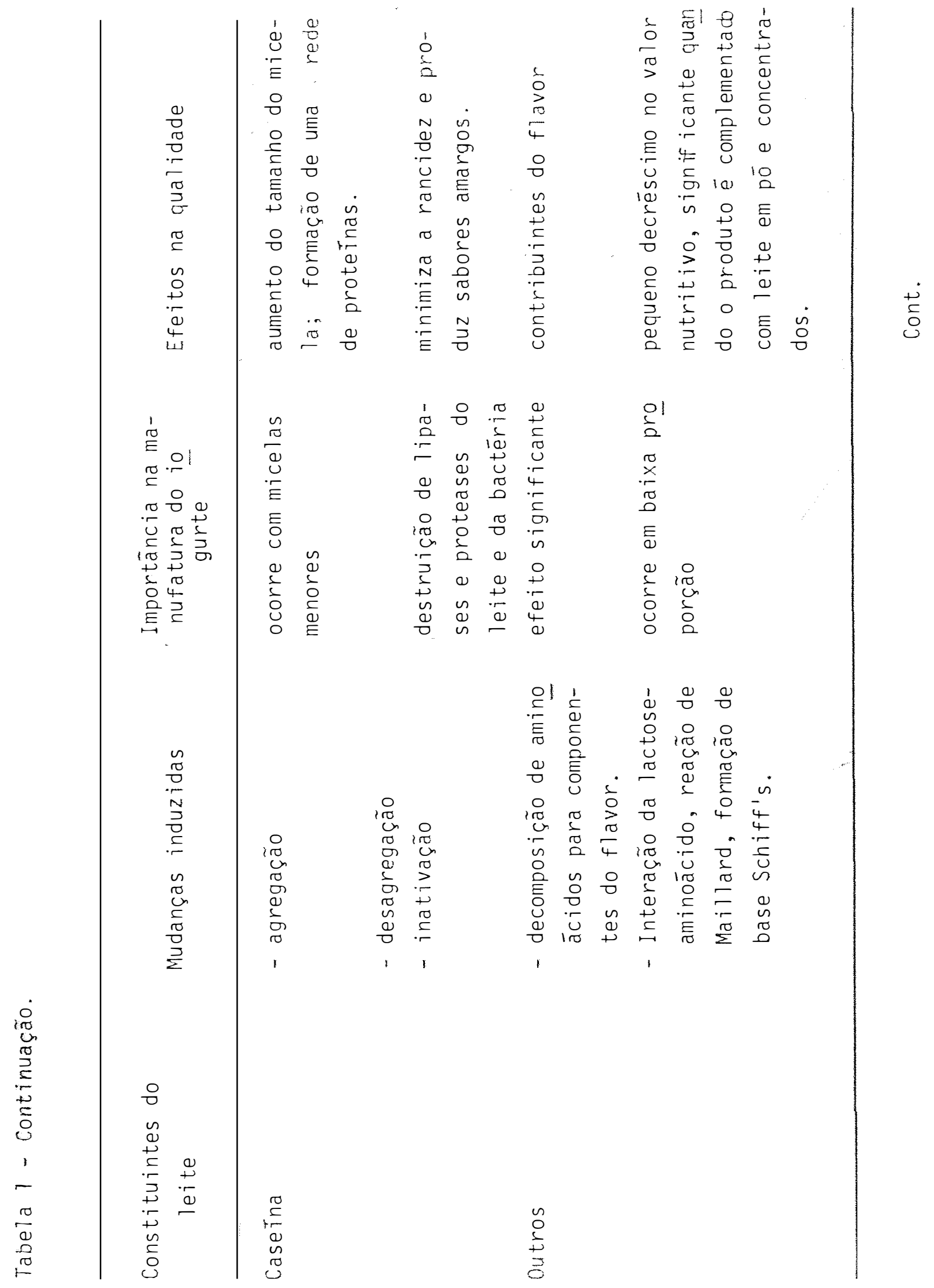




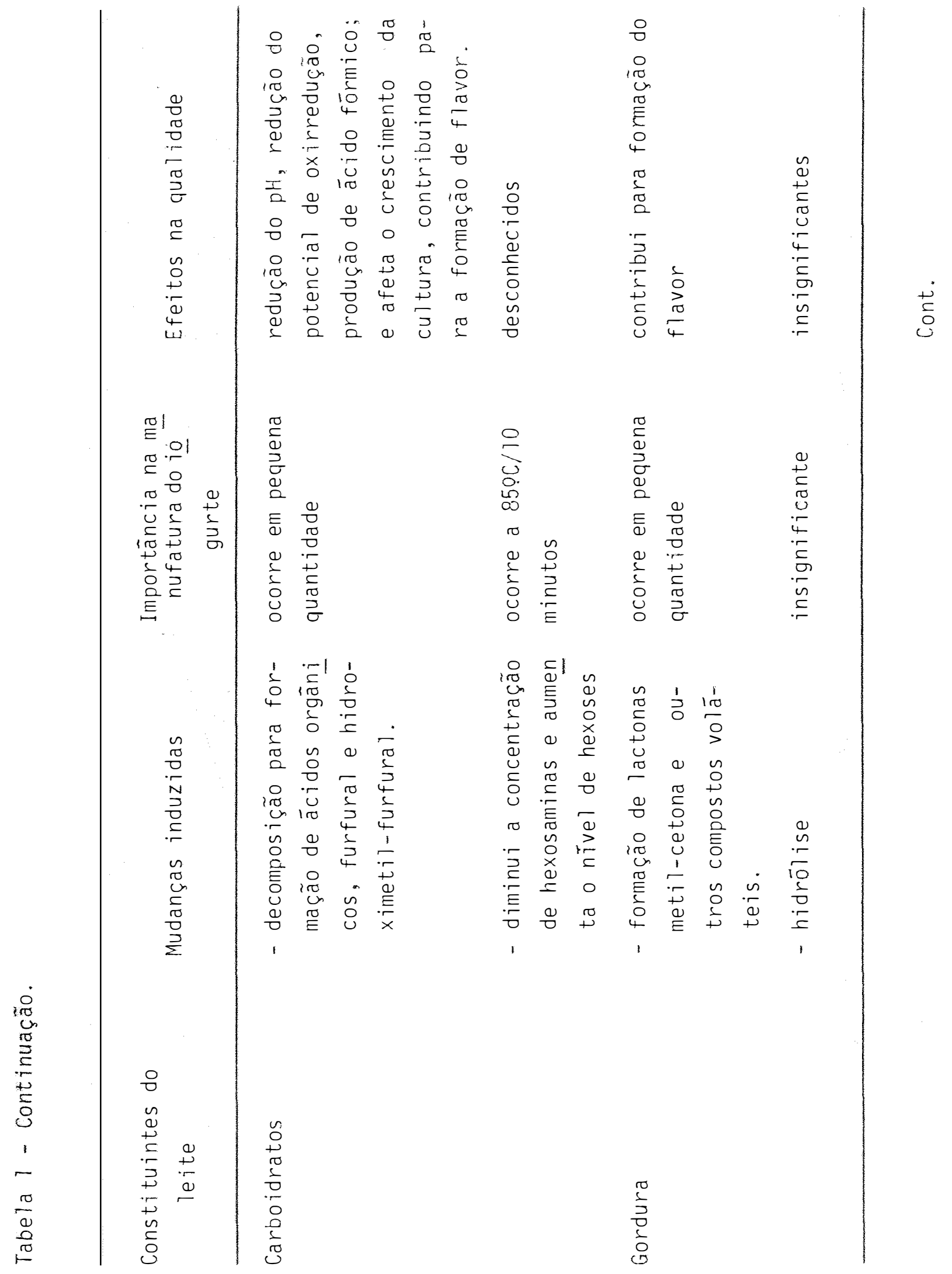


17.

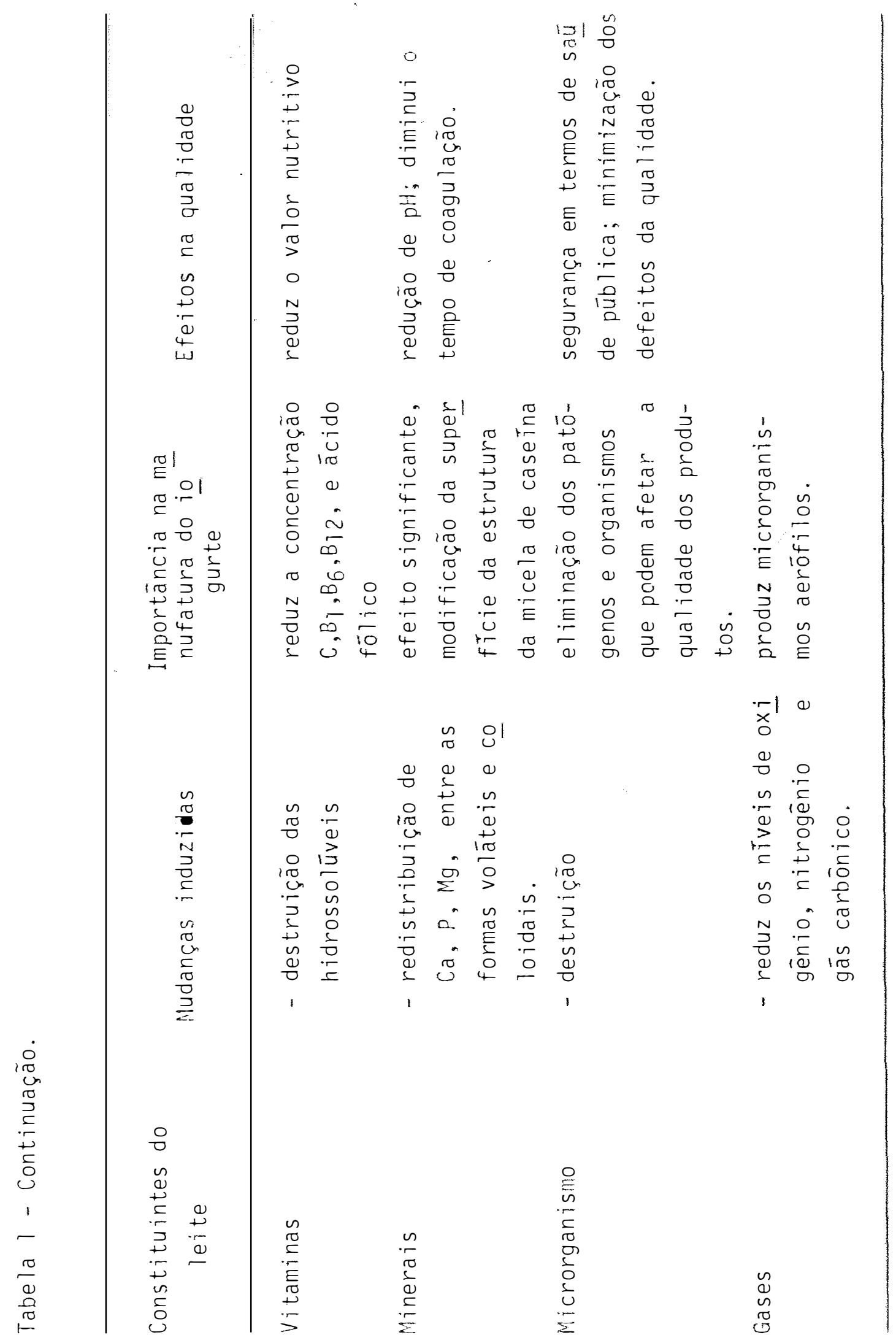


As transformaços físico-químicas da estrutura das proteinas, o abaixamento do pH e o efeito nas proprieda des nutritivas säo as principais mudanças que ocorrem no processamento do rogurte.

As mudanças na fração protéica envolvem as pro teînas do soro e a caseîna e são muito importantes na determinação do gel do iogurte.

A literatura cita que a desnaturação das proteinas pelo calor induz a interações entre as proteínas do so ro e a caseína (LARSON e ROLLERI, 1955; SAWYER, 1969).

Também já foi preconizado que a B-lactoglobuli na inter-reage com a $k$-caseina, mas recentes trabalhos (ELFAGM e WHEELOCK, 1977, 1978a, b) indicaram que a a-lactoalbumina é envolvida.

A intensidade de desnaturação das proteinas do soro pelo calor é mostrada na tabela 2.

Tabelá 2 - Efeito do tratamento térmico nas proteínas do soro. (LARSON et al., 1955).

Proteina

$\%$ Desnaturação 80 c C/30 min. 900 C/30 min.

Imunoglobulinas

s - Lactoglobulina

a - Lactoalbumina
100

90

60
100

100

$90-100$ 
A interaça entre a - lactoglobulina e a caserna é muito importante. Hà um aumento das propriedades hidrofiticas da caseína (GRIGOROV, 1966b, c) e facilidade na formação e na estabilidade do coägulo.

o tratamento térmico tambēm diminui o tempo de fermentação (KALAB et $\underline{\text { a }}$., 1976), e isto é particularmente de vido a uma diminuição do pH. Também jā foi verificado que o efeito da hidratação é máximo quando o leite é aquecido a 85ọc, mas diminui quando a temperatura é superior a 850 C (PRODANSKI, 1967; IYENGAR et al., 1967); isto se reflete adversamente na qualidade do iogurte (GALESLOOT e HASSING, 1969).

A Tabela 3, adaptada por GRIGOROV (1966b), mos tra a diminuição no tempo de coagulação, pH, concentração de àcido lático - em leite aquecido por 30 minutos - em relação a outra mistura aquecida à mesma temperatura e resfriada imediatamente.

Pesquisas realizadas com o objetivo de verificar o efeito do tratamento térmico do leite na performance de alguns "strains", por DUTTA e colaboradores (1973), mostraram que havia uma pequena melhora no leite aquecido a 850 c por 10 minutos, quando comparado com aquele aquecido a 630 c por 30 minutos.

De fato, houve uma significativa redução na atividade proteolitica dos organismos no leite que foi submetido ao tratamento mais rigoroso. Porém, outros pesquisadores verificaram que havia um estimulo no crescimento dos organis- 
Tabela 3 - Efeito do tratamento térmico no processo de coagulaçao. (GRIGOROV, 1966b).

Tratamento térmico do leite

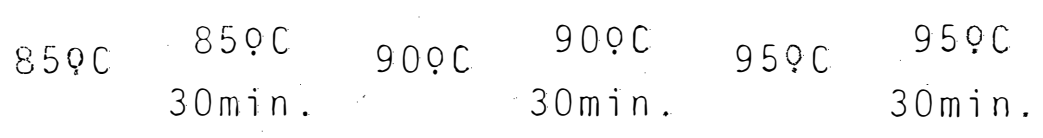

tempo de coà-

gulaçäo (h)

2.43

2. 01

2.34

2.04

2.29

2.04

acidez $(\%)$

0.63

0.49

0.63

0.50

0.63

0.50

$\mathrm{pH}$ de coagu-

l ação

4.70

5.16

4.78

5.12

4. 80

5. 0.8

mos, principalmente devido à destruição das lacteninas (STORGARDS, 1964; HUMPHREYS e PLUNKETT, 1969) e à formação de subs táncias estimulantes do crescimento, tais como peptídios, ami noàcidos e àcido fórmico.

Um estudo realizado por STORGARDS (1964) mostrou que a esterilização a 1340 c é inferior à pasteurização a 800 c por 30 minutos, devido à precipitação incompleta das pro teînas do soro.

Portanto, $\vec{e}$ de fundamental importäncia o delineamento do tratamento térmico a que será submetida a matēria - prima, porque, conforme as discussões citadas anteriormente, o tratamento térmico tem um papel decisivo na qualidade do produto que se deseja. 
KURMANN (1977) relatou que a homogeneização do leite não é um tratamento indispensāvel, mas è recomendada pa ra melhorar a consisténcia do iogurte, efetuando uma melhor distribuiçäo dos glöbulos de gordura, para provocar uma desna turação suplementar das proteínas do soro, melhorar o sabor, tornando-o mais cremoso, produzir um iogurte mais homogéneo e melhorar a digestibilidade.

Esta operação pode ser realizada antes do tratamento térmico (STORGARDS, 1964; MARTENS, 1972), mas, em alguns casos, pode ser feita apōs o tratamento térmico (GIRGINOV, 1971; BRINK, 1971; NIKOLOV e CHERNEV, 1967).

E um processo importante quando as indústrias adicionam leite em pō à matēria-prima.

0 aumento da viscosidade, através do processo de homogeneização, é relatado como a mudança da capacidade de retenção de àgua das proteínas do leite.

GALESLOOT (1958) estudou o efeito da homogene zação na produção de iogurte e concluiu ser ela essencial para a obtenção de um produto de boa consisténcia.

Etapa importante no processamento do iogurte $\vec{e}$ aquela em que ocorre a acidificação do leite e a formação do produto pela ação das bactērias läticas.

A flora normal do iogurte é constituída pelo Lactobacillus bulgaricus e pelo streptococcus thermophikus, que, vivendo em simbiose, legam ao produto final as suas carac teristicas fisicas, quimicas e nutricionais (BOTTAZZI, et 
al., 1971; BOTTAZZI, 1973). O Lactobacillus bulgaricus, atuan do sobre as proteínas, Tibera aminoácidos que estimulam o desenvolvimento da espēcie Streptococcus thermophilus, que por sua vez produz àcido fórmico, necessārio ao desenvolvimentodo Lactobacillus bulgaricus. A reciprocidade desta simbiose parece estar ligada à proporção das duas espécies, durante a fer mentação, alcançando na primeira etapa a proporção de 3:1 de Streptococcus para Lactobacillus, começando o ültimo a predominar nas fases seguintes (SURAZYNSKI, 1975a).

Conforme relatou DAVIS (1975), o melhor cresci mento do Streptococcus lactis ocorre a pH 6.5, parando a pH 4.2 - 4.4. Para o Lactobacillus bulgaricus, o crescimento se realiza a pH 5.5, cessando o desenvolvimento na faixa de pH $3.5-3.8$.

A acidificação ocorre exponencialmente durante - desenvolvimento da cultura mista e prossegue ainda ativamen te quando cada um dos organismos atinge a sua população māxima. (KURMANN, 1977 ).

HUMPHREYS et a 7. (1969) afirmaram que ambos os microrganismos transformam a lactose em àcido lätico e traços de subprodutos que são importantes para produzir o flavor caracteristico. O Streptococcus produz diacetil e o Lactobacillus produz acetaldeîdo. O controle desta proporção, segundo estudos realizados por DEMETER (1969), reveste-se então de especial importäncia, devendo ser encontrado ao redor de 100 Lactobacillus para cada 120-200 streptococcus. Esta proporção se 
altera em favor das termobactërias, ao serem semeadas maiores quantidades destas ou ainda devido ao aumento de temperatura, determinando uma acidez bem mais intensa.

A existēncia de interações entre estas duas bactērias, favorāveis ao desenvolvimento da associação bacteriana, à acidificação e à formação do aroma foi demonstradaem um certo numero de casos ACCOLAS, (1977); BARBER, (1962); FER REIRA, (1978).

PETTE e LOLKEMA (1951b); estudando os fatores que afetam a proporção dos componentes da cultura lātica, con cluîram que a manutenção de um bom equilî̉brio entre as duas espécies bacterianas de culturas mistas, durante as sucessivas repicagens, ē uma tēcnica desejāvel, e uma relação $1: 1$ de Streptococcus e Lactobacillus è geralmente considerada ōtima. Temos visto que é possível a manutenção desta relação, entretanto, como sugere o estudo de PUHAN e BANHEGYI (1974) sobre duas culturas mistas, a obtenção de uma cultura mista estāvel pode requerer algumas vezes uma dezena de repicagens preliminares.

Segundo trabalhos realizados por PETTE (1950) e PUHAN et al. (1974), a manutenção do equilỉbrio entre Streptococcus e Lactobacillus, a produção de ācido e de aroma depende das linhagens, do ajustamento do inōculo, do tempo e da temperatura de incubação e, eventualmente, do nümero de repicagens. E conforme AUCLAIR (1964) e VASSAL e AUCLAIR (1966), 
o desenvolvimento destas bactérias e a produção concomitante de àcido dependem da qualidade do leite utilizado e do tratamento térmico a que o leite foi submetido.

ACCOLAS (1977), estudando a produção de àcido de culturas que foram incubadas em temperaturas que variaram entre 35 e 50ọc, verificou variações na medida da acidez titu lável em função da temperatura de incubação. O Lactobacillus bulgaricus apresenta uma temperatura de crescimento ötima ao redor de 450C, e, segundo HELFERICH (1980), tanto o Lactobacillus como o Streptococcus podem ser classificados como termófilos.

o trabalho realizado por ACCOLAS (1977) sobre culturas individuais de Streptococcus e Lactobacillus mostrou que a atividade acidificante máxima ocorre a uma temperatura de 42-450 para o Staptococcus e a redor de 44-460 para o Lactobacillus. A cultura mista composta por Streptococcus e Lactobacillus apresenta uma atividade acidificante máxima no intervalo de temperatura correspondente a 35-4300. A acidificação ocorre exponencialmente durante o crescimento da cultura mista e prossegue ainda ativamente quando cada um dos orga nismos atinge a sua população mäxima.

De acordo com KURMANN (1977), temperaturas inferiores a 400 C favorecem apenas o desenvolvimento de Streptococcus lactis, provocando um desequilibrio na proporçăo Streptococcus lactis! Lactobacillus bulgaricus. Es te desequi] i brio não é recomendado por trazer conseqüências às qualidades 
organoléticas do produto. E como fator dependente da tempera tura, da relação streptococcusllactobacillus, sua proporção e sua fase de crescimento, tem-se o tempo de fermentação. Deve ser mînimo, para não arriscar uma superacidificação atē o resfriamento do produto, e deve ser suficiente para assegurar a formação das substāncias aromāticas.

Portanto, as culturas de iogurte são misturas de "strains" de Streptococcus thermophilus e Lactobacillus bulgaricus, que normalmente são desenvolvidas em temperaturas ao redor de 420 C.

Entretanto, a escolha da temperatura de incuba ção depende: da adaptação das bactérias a uma determinada tem peratura, considerada a temperatura ótima de cultivo; da capacidade de produção de substāncias desejadas; das instalações técnicas disponiveis para o resfriamento e das condições atmosféricas para reduzir a pōs-acidificação.

A concentração de cultura a ser utilizada serā função: do seu poder acidificante; do tempo de incubação dese jado; da riqueza em células bacterianas; da fase de crescimen to na qual se encontra a cultura; da relação Lactobacillus/ Streptococcus; do teor de sölidos, uma vez que, quando este valor é muito elevado, a acidificação se faz mais lentamente. A porcentagem de inoculação deve ser mỉnima, com o objetivo de impedir uma acidificação muito intensa, e normalmente se trabalha com o nivel de $3 \%$, ou menos. 
o sucessivo subcultivo pode levar à mutação de um outro organismo, por isso $\bar{e}$ importante o acompanhamento da c.sura, através da microscopia, geralmente usando o método de Breed (SCHONHERR, 1959).

Este acompanhamento tambēm é essencial, sob o aspecto de manutenção da proporcionalidade entre os organis mos, que deve ser de 1:1. Para verificação dessa proporciona lidade existem outros métodos, tais como o emprego de meios seletivos que permitem o crescimento de um ou outro organis mo, ou, então, que permitem a identificação morfolōgica dos mesmos.

Os dois mētodos citados acima apresentam vantá gens e desvantagens. 0 método de Breed praticamente se mostra adequado para uma avaliação räpida, na qual o objetivo bāsico seria o conhecimento das condições da cultura sob todos os as pectos.

Os métodos de plaqueamento apresentam desvantä gens sob o aspecto de tempo necessärio para se ter uma respos ta, e, principalmente, em termos econōmicos.

Conforme KURMANN (1977), nos países quentes, alguns parámetros devem ser observados em termos de cultura, uma vez que esta deve apresentar um fraco poder acidificante e pōs-acidificante, e uma alteração da relação Lactobacillus/ Streptococcus, em favor dos Streptococcus. Recomenda tambēm a substituição do Lactobacileus bulgaricus pelo Lactobacillus acidophilus ou Lactobacillus bifidus, e, se a acidificaçäo 
for insuficiente, sugere a adição de 0.01-0.05\% de uma cultura de iogurte clássica, para que o tempo de incubação não se torne muito prolongado.

o tempo de fermentação estā diretamente rela cionado com a temperatura de incubação. E importante procurar um tempo mỉnimo para assegurar a formação de substāncias aromáticas suficientes e para não arriscar uma superacidifica ção até o resfriamento do iogurte.

KURMANN (1977) preconiza também que o tempo de incubação depende de vārios fatores, dentre eles: a atividade da cultura - em termos de produção de ácido e aroma; a relaçao Streptococcus/Lactobacillus; a matēria-prima; a concentra ção da cultura e sua distribuição; sua fase de crescimento; e a introdução ou presença de ar e espuma.

Atualmente, podem-se distinguir duas tendēncias na escolha do tempo de incubação: a incubação no tempo normal de trés horas a 400 c e acima, ou a incubação a 3000 durante dez a doze horas, usando culturas contendo bactérias mesōfi]as.

Apōs o período de incubação, o iogurte deveser rapidamente resfriado. Ao atingir 180 C, o desenvolvimento microbiano é interrompido, e ao atingir o intervalo entre 5... 120 C, a atividade enzimātica chega ao seu limite, conforme re latou REICHART (1978). E, portanto, uma fase muito importante na fabricação do iogurte.

O resfriamento deve ser iniciado assim que o 
iogurte estiver bem coaguiado e apresentando uma acidez 72 760 ou pH 4.7. Em relação a esta etapa do processamento, KuR MANN (1977) relata ainda que é preciso distinguir o resfria mento preliminar, que consiste no abaixamento da temperatura de incubação no final, ou incubação à temperatura regressiva; - resfriamento principal, apōs a incubação; e o resfriamento posterior, que consiste no abaixamento da temperatura apōs o resfriamento principal e abaixamento à temperatura de estocagem.

o resfriamento principal se divide em quatro fases, interessantes de conhecer, para escolna do sistema de resfriamento.

Primeira fase: resfriamento choque - o abaixa mento da temperatura de incubação de 40-450 c para 380̣c deve ser bastante räpido, para causar um choque de frio nas células em vias de multiplicação.

Segunda fase: o resfriamento a $200 \mathrm{C}$ tem como objetivo a paralisação completa da multiplicação bacteriana.

Terceira fase: resfriamento de 1906 para 10 I20 C diminui suficientemente a atividade acidificante.

Quarta fase: redução da temperatura entre 10 120 C para 50̣; consiste na fase de estocagem e conservaçãopro longada. Deve-se ter cuidado para que a temperatura não atinja 0 c , para evitar o congelamento.

No que se refere à conservação pelo frio, não. existe uma solução simples. Para manutenção da acidez do io- 
gurte ao nível desejado, o resfriamento rápido não é suficien te, porque as culturas mistas são capazes de produzir acidifi cação a baixa temperatura. Isto foi relatado por LUEDEKING e PIRET (1959); BERGERE e HERMIER (1968); e FRIEDMAN e GADEN (1970).

De acordo com ACCOLAS (1977), muitos trabalhos mostram que as bactérias láticas na fase estacionāria de cres cimento sāo ainda capazes de produzir bastante àcido. Esta pós-acidificaçāo será tanto majs reduzida quanto menor for o poder acidificante das cuituras. 


\section{MATERIAL E METODOS}

\subsection{Cultura lática}

A cultura lática utilizada para obtenção do io gurte, no presente trabalho, constou de uma mistura na proporção $1: 1$, de Streptococcus thermophilus e Lactobacillus bulgaricus proveniente do Laboratorium WIESBY Gm D \& Co. (Joghurt 709) e que iniciarmente se encontrava na forma liofilizada.

Com o objetivo de manter a atividade da cultura foram realizadas repicagens a intervalos de 48-72 horas, em leite reconstituido desnatado e esterilizado. Nesses mesmos intervalos de tempo, a cultura mista foi examinada a microscópio para verificação da proporcionalidade entre as linhagens e sua viabilidade.

\subsection{Matéria-prima}

Como matéria-prima para elaboração do iogurte 
foi utilizado leite de vaca proveniente do rebano leiteiro da região de Recife - PE. O Teite, imediatamente após a ordenha, foi transportado para o laboratörio e porçōes de $1000 \mathrm{~m}$, cada uma, foram colocadas em Erlenmeyers de $2.000 \mathrm{ml}$, tampadas e submetidas aos tratamentos tērmicos: 650 por 30 minutos; 750 C por 10,20 e 30 minutos e 850 C por 10,20 e 30 minu tos, em banho-maria. A seguir foram resfriadas em àgua corrente até 32,37 e $42 \pm 10$.

\subsection{Inoculação e incubação}

Cada porção de leite, submetida a um diferente tratamento térmico, foi inoculada com 3\%, em volume, da cultura lática. Essa mistura foi dividida em alíquotas de $10 \mathrm{ml}$, distribuidas em tubos de ensaio devidamente esterilizados e contendo tampão de algodão e, a seguir, incubadas a $420 \mathrm{c}$ até a coagulação. Para os tratamentos térmicos a 750 C por 30 minutos e 850 c por 30 minutos, tambēm incubações a 32 e 370 c fo ram utilizadas.

\section{3:4. Anāitises}

3.4.1. Acidez titulàver

A acidez titulävel do leite antes e apös o tra 
tamento térmico e, também, durante a fermentação a cada 20 mi nutos, foi determinada por titulação com solução de hidróxido de sódio 0.l. N, utilizando-se, como indicador, 2 a 3 gotas de uma solução alcoólica de fenolftaleína a l\%.

A seguinte fórmula foi utilizada para o cālcu10 da acidez titulável, expressa em gramas de àcido lático por $100 \mathrm{ml}$ do produto (FERREIRA, 1981):

acidez titulāvel (\% de āc. lätico) $=\frac{V \times f \times 0.009}{A} \times 100$,

onde;

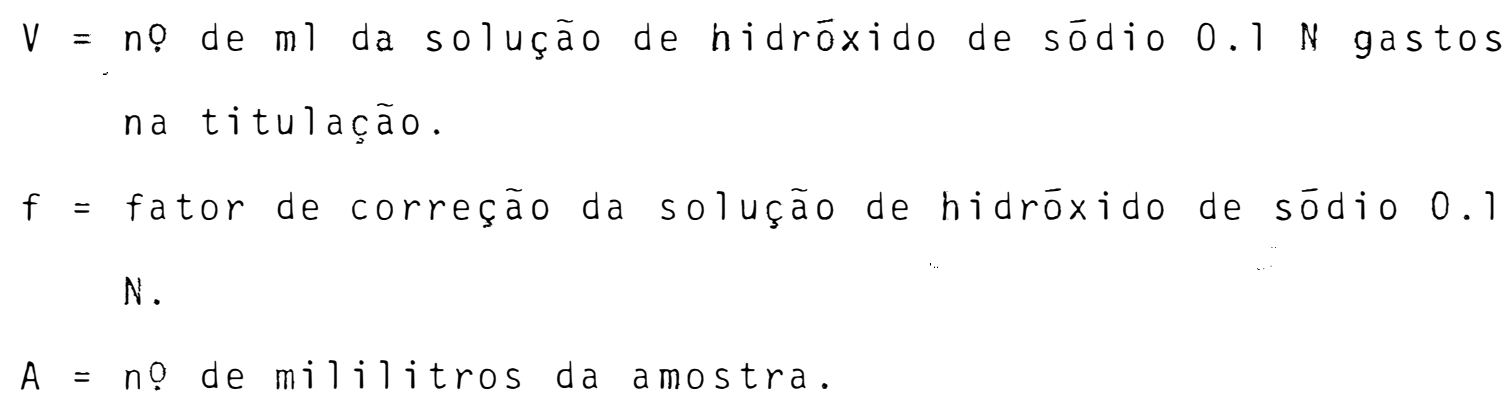

3.4.2. $\mathrm{pH}$

o pH foi determinado através do uso de poten ciómetro, devidamente calibrado.

3.4.3. Sólidos totais

A porcentagem de sólidos totais no leite, an- 
tes e apōs o tratamento tërmico, foi determinada utilizando. se o método descrito em A AC (1970).

3.4.4. Contagem dos microrganismos

Numa tentativa de acompanhar a relação $S$. ther mophillus: L. bulgaricus, durante o transcorrer da fermenta ção, foi feita a contagem desses microrganismos utilizando-se o método da contagem em placas de Petri, com meios especifi cos para S. thermophillus (Agar Casoy - Merck) e para L. bulgaricus (Rogosa Agar - Merck), de acordo com TAMIME et al., $(1980)$.

As placas de Petri, apōs inoculação, foram cỡ 10 cadas em estufa por 72 horas a $370 \mathrm{C}$, apōs o que foram feitas as contagens de colōnias em contador tipo quebec. Em ambos os casos foram realizadas tēcnicas para crescimento anaeröbio.

3.4.5. Anāitise sensorial

Os atributos sabor, aroma e textura dos iogurtes obtidos com leite submetido aos diferentes tratamentos tér micos foram avaliados por uma equipe composta de dez degustadores previamente treinados para degustação de iogurte e para o tipo de anālise empregada. O modelo da ficha de avaliação sen sorial utilizada é mostrado na figura 1 . 


\section{TESTE DE PREFERENCIA}

Nome:

Data:

Produto:

Avalie estas amostras quanto ao flavor. Prove cada uma. Use a escala apropriada para mostrar sua avaliação e identifique o ponto que me lhor descreve o que voce sentiu acerca do flavor da amostra.

CODIGO

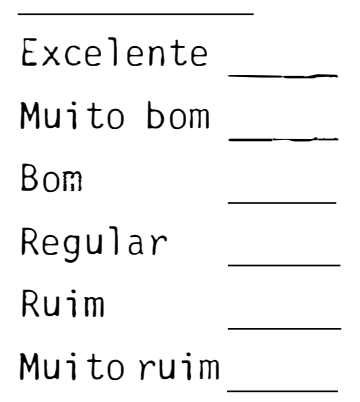

CōDIGO

Excelente

Muito bom

Bom

Regular

Ruim

Muito ruim
CODIGO

\section{Excelente}

Muito bom

Bom

Regular

Ruim

Muito ruim

Razāo da sua classificação:

Figura $?$ - Modelo da ficha utilizada na avaliação sensorial. 
o produto foi obtido respeitando-se as mesmas condiçoes técnicas empregadas durante os ensaios realizadospa ra acompanhamento do pH e acidez (3.7.; 3.2. e 3.3.), e as circunstāncias exigidas para aplicação do teste sensorial foram cumpridas ou adaptadas a cada situação.

Para avaliação dos resultados obtidos através da anälise de variāncia (AMERINE, 1965), apōs a realizaçãodo teste sensorial foram atribuidos valores de 1 a 6 às classifi cações muito ruim, ruim, regular, bom, muito bom e excelente, respectivamente. A escolha do melhor tratamento foi feita le vando-se em consideração a soma dos pontos obtidos.

Para observar a influëncia do tempo de armazenamento, durante dez dias, a uma temperatura de 300 , sobre a qualidade do iogurte, escolheram-se os dois melhores tratamen tos, submetendo, posteriormente, os produtos obtidos ao teste triangular (AMERINE, 1965). Os testes foram realizados nos períodos de $1,3,5,7$ e 10 dias, acompanhados das determinações do pH e acidez. O modelo da ficha de avaliação é mos trado na figura 2 . 


\section{TESTE TRIANGULAR}

Nome:

Data:

Produto:

Nesta prova, duas das trēs amostras são iguais e uma è diferente. Assinale, por favor, a amostra diferente.

Nọ da amostra diferente

Indique o grau de diferença entre a duplicata de amostras e a amostra diferente.

LEVE

MODERADO
GRANDE

EXTREMO

Aceitabilidade:

A amostra diferente é mais aceitāve?

A duplicata de amostras é mais aceitável

Comentārios:

Figura 2 - Modelo da ficha utilizada na avaliação sensorial. 


\section{RESULTADOS E DISCUSSAOO}

\subsection{Características principais da matēria-prima}

os valores obtidos para pH, acidez titulàvel e sōlidos totais do leite antes e apōs os tratamentos térmicos a 650C por 30 minutos, $750 \mathrm{C}$ por 10,20 e 30 minutos e $850 \mathrm{C}$ por 10,20 e 30 minutos, encontram-se expressos nas tabelas 4, 5 e 6. Nessas tabelas, cada valor representa a média de trës repetições, enquanto os valores de cada uma dessas repetições encontram-se no apēndice (tabelas 1, 2 e 3).

os resultados obtidos mostram que praticamente nenhuma alteração ocorreu nessas três características do leite (pH, acidez e teor de sōlidos), em função dos diferentes tratamentos térmicos empregados, embora, no que diz respeito ao pH, TAMIME et al. (1980) e KALAB et al. (1976) afirmem ser o tratamento térmico do leite responsāvel por um abaixamento do $\mathrm{pH}$. 
Tabela 4 - Características principais do leite antes e após o tratamento térmico a $650 \mathrm{C}$ por 30 minutos.

Caracteristicas

antes

a pōs

$\mathrm{pH}$

6.90

6.83

acidez tituràvel

0.77

0.18

sōlidos totais

13.76

14.20

Tabela 5 - Características principais do leite antes e apōs o tratamento térmico a $750 \mathrm{C}$ por 10,20 e 30 minutos.

\begin{tabular}{|c|c|c|c|c|c|c|}
\hline \multirow{2}{*}{ Caracteristicas } & \multicolumn{2}{|c|}{$750 \mathrm{c} / 10 \mathrm{~min}}$. & \multicolumn{2}{|c|}{ 750̣/20 min. } & \multicolumn{2}{|c|}{$759 \mathrm{C} / 30 \mathrm{~min}}$. \\
\hline & antes & $\operatorname{apōs}$ & antes & apōs & antes & apōs \\
\hline $\mathrm{pH}$ & 6.83 & 6.85 & 6.90 & 6.90 & 6.97 & 6.93 \\
\hline acidez titulāvel & 0.20 & 0.20 & 0.16 & 0.16 & 0.19 & 0.20 \\
\hline sólidos totais & 13.14 & 13.14 & 13.70 & 13.70 & 14.66 & 13.92 \\
\hline
\end{tabular}

4.2. Acidez titulāvel e $\underline{p H}$

os valores obtidos para pH e acidez titulável durante a fermentação do leite, previamente submetido a diferentes tratamentos térmicos e incubado a diferentes temperatu 
Tabela 6 - Caracteristicas principais do leite antes e após o tratamento térmico a 850 C por 10,20 e 30 minutos.

\begin{tabular}{|c|c|c|c|c|c|c|}
\hline \multirow{3}{*}{ Caracteristicas } & \multicolumn{2}{|c|}{$8500 / 10$ min. } & \multicolumn{2}{|c|}{$850 \mathrm{c} / 20 \mathrm{~min}}$. & \multicolumn{2}{|c|}{$850 \mathrm{c} / 30 \mathrm{~min}$} \\
\hline & $\ldots \ldots$ & $\ldots$ & $\ldots \ldots$ & $\ldots$ & $\ldots$ & $\ldots$ \\
\hline & antes & apös & antes & apös & antes & apös \\
\hline $\mathrm{pH}$ & 6.75 & 6.58 & 6.95 & 6.87 & 6.88 & 6.85 \\
\hline acidez titurável & 0.13 & 0.14 & 0.16 & 0.16 & 0.17 & 0.17 \\
\hline sólidos totais & 11.88 & 11.87 & 12.35 & 12.63 & 12.71 & 12.65 \\
\hline
\end{tabular}

ras, encontram-se expressos nas tabelas 7, 8, 9, 10 e 11 . Nes sas tabelas, cada valor representa a média de três repetições, enquanto que os valores de cada uma dessas repetições encon tram-se no apēndice (tabelas 4,5 e 6 ).

Analisando os resultados obtidos em relação à acidez expressa em àcido lático, observa-se que para o tratamento térmico a 650 c por 30 minutos a acidez média foi de $0.78 \%$ em ácido lático; para os tratamentos a 750 C por 10,20 e 30 minutos os valores médios situam-se entre $0.71-0.86 \%$ em àcido lático; e $0.66-0.80 \%$ em ácido lático para os tratamen tos a $850 \mathrm{C}$ por 10,20 e 30 minutos, todos a uma temperaturade incubação igual a 420 C.

Verifica-se também que para os tratamentos a 850 C por 10,20 e 30 minutos houve tendéncia para o aumentona acidez, expressa em äcido lático, à proporção que o tempo de 
Tabela 7 - pH e acidez titulävel durante a fermentaçăo do lej te previamente aquecido a $650 \mathrm{C}$ por 30 minutos. Tem peratura de incubação: $420 \mathrm{C}$.

\begin{tabular}{ccc}
\hline $\begin{array}{c}\text { Tempo } \\
\text { (minutos) }\end{array}$ & pH & acidez tituiável \\
\hline 0 & 6.63 & 0.20 \\
20 & 6.47 & 0.22 \\
40 & 6.33 & 0.24 \\
60 & 6.13 & 0.27 \\
80 & 5.82 & 0.31 \\
100 & 5.30 & 0.45 \\
140 & 4.88 & 0.51 \\
160 & 4.67 & 0.62 \\
180 & 4.50 & 0.69 \\
\hline
\end{tabular}

tratamento aumentou. Em relação ao pH, observa-se uma diminuição proporcional ao aumento do tempo, concordando as sim com a citação feita por KALAB et al. (1976), que relaciona a influéncia do tratamento térmico sobre a diminuição do pH.

Entretanto, para os tratamentos a 7500 por 10 , 20 e 30 minutos, os resultados concordam com aqueles obtidos por TAMIME et al. (1980), ros quais, à proporção que se aumenta o tempo, a uma dada temperatura, ocorre a diminuição da acidez final, e, conseqüentemente, um crescente aumento do pH. 
Tabela 8 - pH e acidez titulável durante a fermentação do le te previamente aquecido a $750 \mathrm{C}$ por 10,20 e $30 \mathrm{mi}$ nutos. Temperatura de incubação: $420 \mathrm{C}$.

\begin{tabular}{|c|c|c|c|c|c|c|}
\hline \multirow{2}{*}{$\begin{array}{c}\text { Tempo } \\
\text { (minutos) }\end{array}$} & \multicolumn{2}{|c|}{$759 \mathrm{c} / 10 \mathrm{~min}}$. & \multicolumn{2}{|c|}{$750 \mathrm{C} / 20 \mathrm{~min}}$. & \multicolumn{2}{|c|}{$750 \mathrm{c} / 30 \mathrm{~min}}$. \\
\hline & $\mathrm{pH}$ & acidez & $p \cdot H$ & ac idez & $\mathrm{pH}$ & acidez \\
\hline 0 & 6.67 & 0.24 & 6.82 & 0.19 & 6.90 & 0.23 \\
\hline 20 & 6.63 & 0.25 & 6.73 & 0.22 & 6.85 & 0.24 \\
\hline 40 & 6.47 & 0.29 & 6.67 & 0.24 & 6.83 & 0.25 \\
\hline 60 & 6.27 & 0.30 & 6.50 & 0.26 & 6.78 & 0.26 \\
\hline 80 & 5.77 & 0.38 & 6.40 & 0.29 & 6.68 & 0.27 \\
\hline 100 & 5.57 & 0.51 & 6.07 & 0.37 & 6.57 & 0.33 \\
\hline 120 & 5.30 & 0.63 & 5.77 & 0.45 & 6.35 & 0.40 \\
\hline 140 & 4.83 & 0.70 & 5.44 & 0.55 & 5.60 & 0.51 \\
\hline 160 & 4.63 & 0.77 & 5.50 & 0.66 & 5.60 & 0.61 \\
\hline 180 & 4.50 & 0.86 & 4.90 & 0.72 & 5.23 & 0.71 \\
\hline
\end{tabular}

Analisando ainda os tratamentos a 650 C, 750 C e $850 \mathrm{C}$ por 30 minutos, observa-se que no primeiro tratamento a acidez é de $0.78 \%$ em ácido lático e pH igual a 4.38; para 750 C por 30 minutos a acidez é de $0.71 \%$ e pH igual a 5.23 , e para 850 C por 30 minutos os resultados obtidos foram de $0.80 \%$ em àcido lático e pH igual a 4.75 .

Verifica-se, através desses dados, que no tratamento a $750 \mathrm{C}$ por 30 minutos, os resultados foram inferio- 
Tabela 9 - pHe acidez titulävel durante a fermentação do lej te previamente aquecido a $850 \mathrm{C}$ por 10,20 e $30 \mathrm{mi}$ nutos. Temperatura de incubação: $420 \mathrm{C}$.

\begin{tabular}{|c|c|c|c|c|c|c|}
\hline \multirow{3}{*}{$\begin{array}{c}\text { Tempo } \\
\text { (minutos) }\end{array}$} & \multirow{2}{*}{\multicolumn{2}{|c|}{$850 \mathrm{c} / 10 \mathrm{~min}}}$. & \multirow{2}{*}{\multicolumn{2}{|c|}{$85 \div \mathrm{C} / 20 \mathrm{~min}}}$. & \multirow{2}{*}{\multicolumn{2}{|c|}{$850 \mathrm{c} / 30 \mathrm{~min}}}$. \\
\hline & & & & & & \\
\hline & pH & acidez & $\mathrm{pH}$ & acidez & pH & acidez \\
\hline 0 & 6.69 & 0.17 & 6.55 & 0.20 & 6.65 & 0.22 \\
\hline 20 & 6.59 & 0.18 & 6.26 & 0.23 & 6.57 & 0.24 \\
\hline 40 & 6.39 & 0.20 & 5.81 & 0.25 & 6.50 & 0.28 \\
\hline 60 & 5.93 & 0.25 & 5.49 & 0.33 & 6.36 & 0.31 \\
\hline 80 & 5.79 & 0.29 & 5.14 & 0.41 & 6.16 & 0.33 \\
\hline 100 & 5.17 & 0.39 & 4.96 & 0.52 & 5.79 & 0.46 \\
\hline 120 & 4.75 & 0.52 & 4.55 & 0.56 & 5.32 & 0.57 \\
\hline 140 & 4.62 & 0.60 & 4.38 & 0.60 & 5.09 & 0.67 \\
\hline 160 & 4.49 & 0.63 & 4.15 & 0.66 & 4.90 & 0.69 \\
\hline 180 & 4.42 & 0.66 & 3.99 & 0.74 & 4.75 & 0.80 \\
\hline
\end{tabular}

res em relação a acidez e pH, e a explicação para que nesse tratamento os produtos tenham apresentado melhores caracterís ticas em relação à estabilidade do coàgulo, provavelmente é devida a interação entre a \& - lactoglobulina e a caseína, e ao melhoramento das propriedades hidrofilicas da caseína. (TA MIME et al., 1980). Temperaturas inferiores ou superiores a essa provavelmente não provocam as mudanças desejäveis em reiaçăo à desnaturação das proteínas. 
Tabela 70 - pH e acidez titulável durante a fermentação do lej te previamente aquecido a $750 \mathrm{C}$ por 30 minutos. Temperaturas de incubação $320 \mathrm{C}$ e $370 \mathrm{C}$.

\begin{tabular}{|c|c|c|c|c|}
\hline \multirow{2}{*}{$\begin{array}{c}\text { Tempo } \\
\text { (minutos) }\end{array}$} & \multicolumn{2}{|c|}{$32 \div \mathrm{C}$} & \multicolumn{2}{|c|}{$37 \div 0$} \\
\hline & $\mathrm{pH}$ & acidez titulāvel & $\mathrm{p} \cdot \mathrm{H}$ & acidez titulāvel \\
\hline 0 & 6.60 & 0.18 & 6.56 & 0.17 \\
\hline 20 & 6.55 & 0.20 & 6.51 & 0.21 \\
\hline 40 & 6.50 & 0.21 & 6.46 & 0.26 \\
\hline 60 & 6.35 & 0.24 & 6.10 & 0.25 \\
\hline 80 & 6.19 & 0.25 & 5.53 & 0.33 \\
\hline 100 & 5.96 & 0.27 & 5.28 & 0.42 \\
\hline 120 & 5.91 & 0.26 & 5.27 & 0.46 \\
\hline 140 & 5.70 & 0.31 & 4.96 & 0.55 \\
\hline 160 & 5.44 & 0.36 & 4.44 & 0.62 \\
\hline 180 & 5.20 & 0.42 & 4.24 & 0.66 \\
\hline 200 & 4.90 & 0.42 & 4.19 & 0.67 \\
\hline 220 & 4.70 & 0.51 & 4.14 & 0.73 \\
\hline 240 & 4.68 & 0.56 & - & - \\
\hline 260 & 4.61 & 0.62 & - & - \\
\hline
\end{tabular}

Segundo GRIGOROV (1966b), o tratamento térmico apresenta uma relação com o tempo de coagulação, uma vez que tratamentos mais rigorosos destroem as lacteninas (STORGARDS, 1964; HUMPHREYS e PLUNKETT, 1969) e dão origem a peptĩ dios, aminoācidos e àcido förmico, substäncias estimulantes do desenvolvimento da cultura lātica (MILLER et al., 1954). 
Tabela 11 - pH e acidez titulável durante a fermentaçāo dolei te previamente aquecido a $859 \mathrm{C}$ por 30 minutos. Tem peraturas de incubação $320 \mathrm{C}$ e $370 \mathrm{C}$.

\begin{tabular}{|c|c|c|c|c|c|}
\hline \multirow{2}{*}{$\begin{array}{c}\text { Tempo } \\
\text { (minutos) }\end{array}$} & \multicolumn{2}{|c|}{3290} & \multicolumn{3}{|c|}{$370 \mathrm{C}$} \\
\hline & $\mathrm{pH}$ & acidez titulāvel & $\mathrm{pH}$ & acidez & titulāvel \\
\hline 0 & 6.84 & 0.17 & 6.85 & & 0.18 \\
\hline 20 & 6.68 & 0.19 & 6.71 & & 0.21 \\
\hline 40 & 6.60 & 0.21 & 6.62 & & 0.24 \\
\hline 60 & 6.45 & 0.22 & 6.45 & & 0.27 \\
\hline 80 & 6.26 & 0.27 & 6.21 & & 0.30 \\
\hline 100 & 6.16 & 0.29 & 5.85 & & 0.35 \\
\hline 120 & 5.98 & 0.38 & 5.64 & & 0.40 \\
\hline 140 & 5.82 & 0.40 & 5.37 & & 0.44 \\
\hline 160 & 5.70 & 0.43 & 5.16 & & 0.46 \\
\hline 180 & 5.59 & 0.47 & 4.94 & & 0.58 \\
\hline 200 & 5.34 & 0.54 & 4.78 & & 0.65 \\
\hline 220 & 5.13 & 0.61 & 4.66 & & 0.67 \\
\hline 240 & 4.96 & 0.64 & - & & - \\
\hline 260 & 4.83 & 0.67 & - & & - \\
\hline
\end{tabular}

Os resultados apresentados nas tabelas 7,8 e 9 mostram que o tempo necessārio para que o produto, a cada diferente tratamento tērmico e temperatura de incubação $420 \mathrm{C}$, apresente acidez $0.60-0.70 \%$ em àcido lātico, é em torno de 120 - 140 minutos. Para os tratamentos a 850 C, à proporção que se aumenta o tempo hà um aumento na acidez titulāvel; entre - 
tranto, para os tratamentos a $750 \mathrm{C}$ verifica-se que, à proporção que se aumenta o tempo, a acidez titulàvel diminui, concordando assim com as referēncias feitas por TAMIME et al. (1980) e ao mesmo tempo contrariando as recomendações feitas por KURMANN (1977), que dizem ser de trés horas o tempo mīnimo para elaboração do iogurte, nessas condições.

Entretanto, o tempo deve ser o necessário para assegurar a formação de substāncias aromáticas suficientes e para não arriscar uma superacidificação atē o resfriamento do iogurte.

ACCOLAS (1977), estudando a influéncia da tem1- :atura de incubação sobre o desenvolvimento da cultura misconstituida por Streptococcus e Lactobacillus, verificou e a atividade acidificante máxima estava a redor de 35 430 C. Portanto, observa-se que, provavelmente, temperaturas me nures que 400 C afetarão o tempo necessārio para a coagulação do leite, tornando-a mais lenta.

Os dados apresentados nas tabelas 10 e 11 referem-se à cinética de fermentação, quando amostras de leite foram submetidas a tratamentos térmicos 750 C e 850 c por 30 mi nutos e a temperaturas de incubação iguais a 320 c e 3700 .

Observa-se que para a temperatura de incubação igual a 3700 , ao final de um período correspondente a 220 minutos, o tratamento térmico 750 c por 30 minutos foi mais efetivo em relação à produção de àcido, tendo a média dos produtos, como características principais, acidez a $0.62 \%$ em àci- 
do lätico, pH igual a 4.44 e tempo de coagulaçăo igual a 160 minutos, quando comparado ao tratamento a $850 \mathrm{C}$ por 30 minutos, que apresenta acidez a $0.65 \%$ em ácido lático, pH igual a 4.78 e tempo de coagulação igual a 200 minutos. Nesse caso, verifica-se que a diferença é apenas em relação ao tempo de coagulação do leite.

Em relação à temperatura de incubação igual a $320 \mathrm{C}$, as tabelas 10 e 11 mostram que para o tratamento a $750 \mathrm{C}$ por 30 minutos a acidez é de $0.62 \%$ em ácido lātico, pH igual a 4.61 e tempo de coagulação 260 minutos; e, ao se comparar com os dados obtidos com o tratamento a 850 c por 30 minutos, a diferença é apenas em relação ao tempo de coagulação.

Portanto, provavelmente, o que justifica um tempo maior para a fermentação, a temperaturas menores que 400̣, é a necessidade de formaçäo dos componentes volàteis, conforme relatou KURMANN (1977).

\subsection{Crescimento microbiano}

No presente trabalho, uma tentativa foi feita para se acompanhar o desenvolvimento da cultura lática, emter mos de S. thenmophlus e L. bulgaricus, em cada etapa do processo de fermentaçäo, uma vez que segundo HAMDAN et â]. (197) b) e BOTTAZZI (7973), a relação simbiötica existente entre os microrganismos aumenta o nivel de acetalde Tdo produzido no io 
gurte, e, em geral, o L. bulgarecus é relatado como o mais im portante contribuinte para a produçäo de flavor, apesar de SHANKAR (1977) E SHANKAR E DAVIES (1978) haverem relatado que o S. thenmophilus produz maior quantitade de acetaldeido, pro veniente, inclusive, dos fatores de crescimento do meio.

DAVIS (1975) relatou tambēm a relação existente entre o pH e o desenvolvimento dos microrganismos e, segun do DEMETER (1969), ao final do período de fermentação do leite deve ser encontrada uma proporção de 100 Lactobacillus: 120 - 200 Streptococcus.

Entretanto, os resultados obtidos neste trabaIho nao são satisfatōrios. A dificuldade encontrada em seobter tais resultados poderá estar relacionada com o fato de que no desenvolvimento isolado desses microrganismos em meio sintético, as condições não são idénticas às da mistura básica e tambēm não ocorrem aí condições de simbiose, ou ainda, por mais completo que tenhà sido o meio utilizado, existe a possi bilidade da deficiéncia em algum elemento essencial, uma vez que esses microrganismos säo bastante exigentes em termos nutricionais. Essa exigència se refere principalmente a substāncias nitrogenadas e vitaminas, devendo o meio para seu crescimento conter uma mistura completa de aminoācidos e fatores de crescimento, especialmente vitaminas do complexo B. Dev乞-se levar em consideração também a dificuldade de crescimento desses microrganismos pelo fato de serem anaeróbios facultativos ou microaerófilos. 
4.4. Anälise sensorial

Nas tabelas 12,13 e 14 encontram-se os resultados obtidos para a avaliaça sensorial dos iogurtes processados, a cada vez, com leite submetido a um diferente trata mento térmico.

Tabela 12 - Anälise sensorial dos iogurtes obtidos de leite aquecido a $750 \mathrm{C}$ por 10,20 e 30 minutos, incubado a $420 \mathrm{C}$ por 180 minutos.

Pontos

(1)

$750 \mathrm{C} / 10 \mathrm{~min} . \quad 7.50 \mathrm{C} / 20 \mathrm{~min} .750 \mathrm{C} / 30 \mathrm{~min}$.

Teste

F

\begin{tabular}{|c|c|c|c|c|}
\hline Aroma & 42 & 4.6 & 4.7 & $0,75 \mathrm{~ns}$ \\
\hline Corpo e textura & 35 & 46 & 42 & $5.30 * *$ \\
\hline Sabor & 33 & 39 & 42 & $2.40 \mathrm{~ns}$ \\
\hline Total de pontos & 110 & 131 & 131 & \\
\hline
\end{tabular}

ns - não hā diferença significativa entre as amostras.

** - hà diferença significativa entre as amostras, a nivel de $5 \%$.

(1) - soma dos pontos conferidos pelos dez degustadores.

Observa-se que os tratamentos térmicos 8500por 10,30 e 20 minutos (tabela 12) apresentam esta ordem de magnitude no que diz respeito a aroma, apresentando inclusive di 
Tabela 13 - Anālise sensorial dos iogurtes obtidos de leite aquecido a $850 \mathrm{C}$ por 10,20 e 30 minutos, incubado a $420 \mathrm{C}$ por 180 minutos.

Pontos

(1)

$850 \mathrm{C} / 10 \mathrm{~min} .850 \mathrm{C} / 20 \mathrm{~min} .85 \mathrm{C} / 30 \mathrm{~min}$.
Teste

F

\begin{tabular}{lllll}
\hline Aroma & 49 & 41 & 47 & $5.1^{\star \star}$ \\
Corpo e Textura & 39 & 32 & 41 & $1.1 \mathrm{~ns}$ \\
Sabor & 35 & 32 & 38 & $0.5 \mathrm{~ns}$ \\
\hline Total de pontos & 123 & 105 & 126 \\
\hline
\end{tabular}

ns - não há diferença significativa entre as amostras.

** - há diferença significativa entre as amostras, a nívelde $5 \%$.

(1) - soma dos pontos conferidos pelos dez degustadores.

ferença significativa a nivel de 5\%; enquanto que para consis tência e sabor, a ordem de preferéncia foi 850C por $30>10>$ 20 minutos, embora as amostras entre si, nesses dois casos, não apresentem diferença significativa.

Já para os produtos obtidos a partir dos binomios 750 c por 10,20 e 30 minutos (tabela 13), observa-se que em relação a aroma e sabor a preferēncia está nos tratamentos a 750 C por $30>20>10$, näo havendo entretanto diferença sig nificativa entre as amostras; e, para consisténcia, a ordem 
Tabela 14 - Anälise sensorial dos iogurtes obtidos de leite aquecido a $650 \mathrm{C}, 750 \mathrm{C}$ e 3500 por 39 minutos, in. cubados a $420 \mathrm{C}$ por 180 minutos.

Pontos (1)

Teste

$F$

$650 \mathrm{C} / 30 \mathrm{~min} .75 \mathrm{OC} / 30 \mathrm{~min} .85 \mathrm{C} / 30 \mathrm{~min}$.

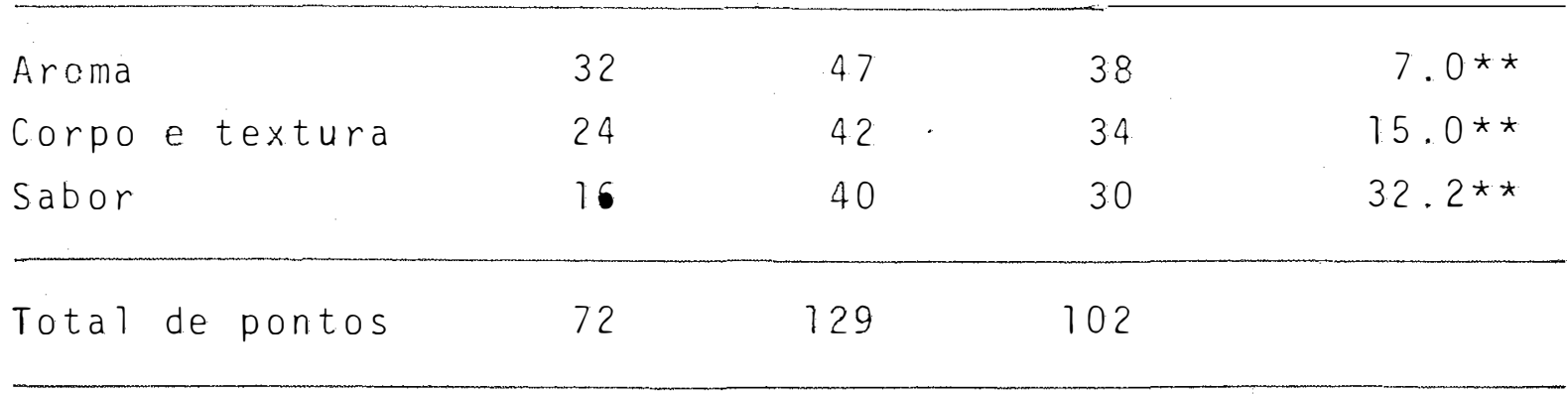

** - hà diferença significativa entre as amostras, anivel de $5 \%$.

(1) - soma dos pontos conferidos pelos dez degustadores.

de magnitude foi para os processamentos a 750 C por $20>30>$ 10, havendo diferença significativa entre as amostras.

A aplicação deste mesmo teste para o melhor pro cessamento, em termos de aroma e sabor, de cada grupo, como tambēm para o tratamento a $650 \mathrm{C}$ por 30 minutos (tabela 74 ), mostra que em relação a aroma, consisténcia e sabor, resultados satisfatōrios foram obtidos quando se empregaram binómios 750 C e 850 C por 30 minutos, havendo entretanto diferença significativa a nivel de $5 \%$

Portanto, tais tratamentos, $750 \mathrm{C}$ e $850 \mathrm{C}$ por 30 minutos, foram os màs efetivos em termos de produzir o io- 
gurte conforme as caracteristicas apresentadas pela literatura, em relação a aroma e sabor, principalmente.

Comparando-se também os resultados obtidos pela anālise sensorial com aqueles mostrados na tabela 8 , verifica-se que os dados estão de acordo com aqueles citados por TAMIME et al. (1980) preconizama influéncia do tempo, a uma dada temperatura, no caso 750 c por 30 minutos, sobre as qualida les organoléticas do produto final.

4.5. Conservação do iogurte sob refrigeração

KURMANN (1977) denominou como pós-acidificação $\therefore$ acidez produzida após o perīodo de incubação, isto é, duran te o resfriamento, estocagem e distribuição, até o consumo; e, segundo SALJI e ISMAL (1983) e TOBA (1983), essa acidez muda durante o armazenamento, em maior ou menor grau, depen = dendo da acidez inicial do produto e da temperatura de armaze namento e do poder acidificante da cultura.

Com a finalidade de acompanhar este fenōmeno e seus efeitos sobre os atributos de qualidade do iogurte, uma vez que a acidez é um dos fatores que limita uma maior aceita ção do produto, procedeu-se a outra sērie de anälises senso riais, aplicando-se nessa etapa o teste triangular aos melhores tratamentos obtidos nesse trabalho.

Paralelamente, foram tambëm realizadas as de- 
terminaçöes de pH e acidez, expressa emäcido lático, e os va lores encontrados estão na tabela 15.

Tabela 15 - pH e acidez titulävel durante o armazenamento, pa ra os tratamentos térmicos $750 \mathrm{C}$ e $850 \mathrm{C}$ por $30 \mathrm{mi}-$ nutos, durante 10 dias, à temperatura de $3 \pm 10 \mathrm{C}$.

\begin{tabular}{ccccc}
\hline Tempo & $750 \mathrm{c} / 30 \mathrm{~min}$ & $85 \mathrm{Cc} / 30 \mathrm{~min}$. \\
$($ dias $)$ & $\mathrm{pH}$ & acidez & pH & acidez \\
\hline 1 & 4.00 & 0.98 & 4.05 & 0.86 \\
3 & 3.85 & 1.16 & 3.90 & 1.12 \\
5 & 4.05 & 1.04 & 4.12 & 1.00 \\
7 & 3.90 & 1.05 & 3.90 & 1.07 \\
10 & 4.09 & 1.04 & 4.12 & 1.02 \\
\hline
\end{tabular}

Tais resultados mostram que, durante o período de armazenamento, o desenvolvimento da acidez foi lento, näo obedecendo a uma ordem em termos de pH; entretanto, para acidez titulävel houve um aumento crescente de $0.06 \%$ em ácido látic.o $(0.98-1.04)$, para o tratamento a $750 \mathrm{C}$ por 30 minutos.

Para 850 C por 30 minutos, a variação é de $0.16 \%$ em äcido lätico $(0.86$ - 1.02) e tambēm não se observa uma ordem em relaça a o pH. 
Entretanto, a anālise sensorial revela que a preferéncia dos provadores variou em funçăo do tempo de armazenamento.

No primeiro dia, os produtos apresentaram diferença significativa e a preferéncia foi dada a iogurte obtido atravēs do tratamento térmico 750 C por 30 minutos. Após trés dias, mantidos à temperatura de $3 \pm 10 C^{2}$ as amostras con tinuaram a apresentar diferença significativa; no entanto, o tratamento térmico 850 c por 30 minutos foi o escolnido.

Aos cinco, sete e dez dias, os produtos jänäo apresentaram mais diferença significativa de preferéncia.

Segundo SALJI e ISMAIL (3983), as mudanças na acidez titulàvel não parecem ser muito afetadas pela acidez inicial, entretanto, tais autores consideram como mais eficaz a avaliação feita através da medida do pH. 


\section{CONCLUSOES}

Após a anālise dos resultados, conclui-se:

1. Os tratamentos térmicos a 8500 por 10,20 e 30 minutos, com posterior incubação do leite à temperatura de $420 \mathrm{C}$, são efetivos em produzir o iogurte com as caracteristicas desejáveis, entretanto, observa-se uma tendéncia para o - .mento na acidez, à proporção que o tempo, a essa temperatu1. a a umenta.

2. Os tratamentos térmicos a 750 C por $10,20 \mathrm{e}$ 30 minutos, seguidos da incubação do leite à temperatura de 4 : $c$, são também efetivos em produzir o iogurte com as características de pH e acidez titulável, sendo no entanto o maior tempo, a essa temperatura, responsável por uma menor acidez do produto.

3. Os tratament s térmicos a 650 C por 30 minutos, composterior incubação do leite a $420 \mathrm{C}$, apresentam pH 
e acidez titulāvel desejāveis; no entanto, é fraca a consis tência do produto.

4. Todos os tratamentos térmicos apresentam, à temperatura de incubação igual a $420 \mathrm{C}$, tempo de coagulação ao redor de 120 - 140 minutos.

5. Os resultados obtidos através da anālise sen sorial mostram que os tratamentos tërmicos 750 C e 850 C por 30 minutos, e posterior incubação à temperatura de $420 \mathrm{C}$, são os mais efetivos em produzir iogurte apresentando as características de aceitabilidade satisfatōrias, com diferença a nível de $5 \%$ entre os produtos.

6. Os tratamentos térmicos a $750 \mathrm{C}$ e $850 \mathrm{C}$ por 30 minutos, com posterior incubação do leite à temperatura de 420. quando armazenados por um perīodo de dez dias, à temperatura de $3 \pm 10 C$, apresentam diferença significativa até 0 terceiro dia; no entanto, aos cinco, sete e dez dias, jā näo se observa mais diferença significativa de preferéncia entre os mesinos.

7. Tendo em vista os resultados anteriormente citados, o tratamento térmico a 750 C por 30 minutos é o mais favorävel à produção do iogurte.

8. Temperaturas de incubação iguais a 370 C e 320 C não aumentam extraordinariamente o tempo de coagulação. 
9. Nenhuma alteraça ocorre em relação a pH, acidez titulàvel. e teor de sōlidos, em funçäo dos diferentes tratamentos térmicos.

10. O acompanhamento da cinētica de fermentação atravēs da técnica de contagem em placas de microrganis mos não apresenta resultados satisfatōrios. 


\section{LITERATURA CITADA}

ACCOLAS, J.P. et al, 1977 . Propiētés Acidificantes des Bacté ries Lactiques Thermophillus en Relation avec la Fabrica tion du Yoghourt. Le Lait, 56 l-562, 1-23.

AMERINE, M.A. et al., 1965. Principles of sensory evaluation of food. New York, Academic Press, $602 \mathrm{p}$.

ANON, 1976a. Cultured Milk Products, Technical Information. "In: TAMINE, A.Y. e DEETH, H.C., 1980. Yogurt: Technology and Biochemistry'. Journal of Food Protection, 43, 939 $977^{\prime \prime}$.

ANON, 1977a. Fermented Milk Process Guide, Technical Informa tion Bulletin No. WM60779, Alfa-Laval A/B, Lund, Swedden. "In: TAMINE, A.Y. e DEETH, H.C., 1980. Technology and Biochemistry'. Journal of Food Protection, 43, 939 - 977".

ASHTON, T.R., 1963, J. Soc. Dairy Technol. 16, 58. "In: HUMPHREYS, C.L. e PLUNKETT, N., 1969. Yogurt: A Review of its Manufacture. Dairy Sci. Abstr., 31 (44): 607 - 22". 
ASSOCIATION OF OFFICIAL ANALYTICAL CHEMISTS, 1970. Official methods of analysis. 11th. Ed. AOAC, Washington. D.C.

AUCLAIR, J., 1964. Les Substances Antibactēriennes du lait cruet leur róle en Technologie Laitière 4 th. Inter. Simpo sium on Food Microbioloay, SIK, Goteborg (Suēde), 281 296. "In: ACCOLAS, J.P., et al., 1977. Propiētes Acidificantes des Bactèries Lactiques en Relation avec la Fabrica tion du Yoghourt. Le Lait, 561-562, 1-23".

BARBER, F.W., 1962. Milk Hygienne, Monograph.Ser.W.H.0.48,405. "In: HUMPHREYS, C.L. e PLUNKETT, M. 1969. Yogurt: A Review of its Manufacture. Dairy Sci. Abstr. 31 (11): $607-22$ ".

BAUSTIAN, H., 1970. Dairy Sci. Abstr. 32, 157. "In: TAMIME, A.Y. e DEETH, H.C., 1980. Yogurt: Technology and Biochemis. try ${ }^{7}$. Journal of Food Protection, 43, $939-977^{\prime \prime}$.

$\therefore$ BECKER, F., 1971. Dairy Sci. Abstr., 33, 884. "In: TAMIME, A. Y. e DEETH, H.C., 1980. Yogurt: Technology and Biochemistry'. Journal of Food Protection, 43, 939 - 977".

BERGERE, J.J. e HERMIER, J., 7968. La Production Massive de Cellules de Streptocoques lactiques II. Croissance de Streptococcus lactis dan un milieu à pH Constant. Le Lait, $48,13-30$.

BOTTAZZI, V. et al., 1971. Continuous Production of Yogurt Cultures and Stimulation of Lactobacillus bulgaricus by Formic Acid. Milchwissenschaft, 26 (4), 214 - 219 . "In: TERRA, N.N. et al., 1977. Estudo do Iogurte Comercializado em Santa Maria, RS. Revista do Centro de Ciēncias Rurais, $7(3), 275-281$. 
BOTTAZZI, $V ., 1973$. Effect of single and Associated Strain of L. bulgaricus and S. thermophilus as well as milk treatment on the Production of Acetaldehyde in yogurt. Le Lait, 53 $(525-526), 295-308$.

BRINK, T. van dien., 1971. Dairy Sci. Abstr., 3, 759. "In: TAMIME, A.Y. e DEETH, H.C., 1980..Yogurt: Technology and Biochemistry'. Journal of Food Protection, 43, 939 - $977 "$.

CARINI, S. et al., 1972. Lipolise Microbica: i lattici. Scienza. e Tecnica Lattiero-Casearia, 23 (6), 377 - 388. "In: MARTINS, J.F.P., 1981. Controle de Culturas Láticas e seu Uso Adequado. Instruções Técnicas. Instituto de Tecnologia de Alimentos, no 17,153 .

COTISLOW, R.N. e SPECK, N.L., 1951. J. Dairy SCi., 34, 1104. "In: HUMPHREYS, C.L. e PLUNKETT, M., 1969. Yogurt: A Review of its Manufacture. Dairy Sci. Abstr., 31 (11), 607 $-22 "$.

DAVIS, J.G., 1967. Dairy Ice-Cream Ind. Dir. 5. "In: TAMIME, A.Y. e DEETH, H.C., 1980. Yogurt: Technology and Biochemis try'. Journal of Food Protection, 43, $939-977^{\prime \prime}$.

DAVIS, J.G., 1971. Dairy Ind. 36, 456. "In: TAMIME, A.Y. e DEETH, H.C., 1980. Yogurt: Technology and Biochemistry'. Journal of Food Protection, 43, $939-977^{\prime \prime}$.

DAVIS, J.G., 1973. Food Manuf., 48, 23. "In: TAMIME, A.Y. e DEETH, H.C., 1980. Yogurt: Technology and Biochemistry". Journal of Food Protection, 43, 939 - $977^{\prime \prime}$. 
DAVIS, J.G., 1975a. IFST Proc., \&, 50. "In: TAMIME, A.Y. e DEETH, H.C., 1980. Yogurt: Technology and Biochemistry?. Journal of Food Protection, 43, 939 - 977".

DEMETER, J.K., 1969. Lactobacteriologia. Zaragosa, Editorial Acribia, 212 p.

DOAN, F.J. e DIZIKES, J.L., 1942. Digestion Characteristic of various types of milk compared with human milk. Pa. Agric. Exp. Sta. no 428. "In: FERREIRA, C.L.L.F., 1978. Elemen tos Composicionais e Aspectos Nutritivos do Leite é Iogurte. Revista do Instituto de Laticinios Cāndido Tostes, 33 $(200): 13-16$.

DORDEVIC, J. et a]., 1973. Dairy Sci. Abstr., 35; 390. "In: TAMIME, A.Y. e DEETH, H.C., 1980. Yogurt: Tecnhology and Biochemistryl. Journal of Food Protection, 43; 939 - 977".

DUTTA, S.M. et al., 1972. Effect of incubation temperature on acid flavor production in milk by lactic acid bacteria. J. Milk Food Technol., 35 (4), 242 - 244 .

DUTTA, S.M. et al., 1973. Milchwissenschaft 28, 231. "In: TAMIME, A.Y. e DEETH, H.C., 1980. Yogurt: Technology and Biochemistry'. Journal of Food Protection, 43, 939 - 977".

ELFAGM, A.A. e WHEELOCK, J.V., 1977. J. Dairy Res. , 44, 367. "In: TAMIME, A.Y. e DEETH, H.C., 1980. Yogurt: Technology and Biochemistryl. Journal of Food Protection, 43, 939 $977^{\prime \prime}$.

ELFAGM, A.A. eWHEELOCK, J.V., 1978a. J: Dairy SCi., 61, 28. "In: TAMIME, A.Y. e DEETH, H.C., 1980. Yogurt: Tecnology and Biochemistry'. Journal of Food Protection, 43, 939 - 977". 
ELFAGM, A.A. e WHEELOCK, J.V., 1978b. J. Dairy Sci., 63, 159. "In: TAMIME, A.Y. e DEETH, H.C., 1980. Yogurt: Technology and Biochemistry'. Journal of Food Protection, 43, 939 $977^{\prime \prime}$.

FAO/WHO, 1973. Code of Principles Concerning Milk \& Milk Products. cx. 5/70, 16th. Session, Rome, Italy.

FERREIRA, C.L.L.F., 1978. Elementos Composicionais e Aspectos Nutritivos do Leite e Iogurte. Revista do Instituto de Laticínios cãndido Tostes, 33 (200): 13 - 16 .

FERREIRA, C.L.L.F., 1981. Caracterização do Iogurte Comercializado na Zona da Mata, Minas Gerais. Revista do Instituto de Laticīnios Cāndido Tostes, nov-dez, 27-31.

FREITAS, J., 1971. Valor Nutritivo do Leite e Derivados sob Aspecto Bioquimico. Revista do Instituto de Laticínios Cán dido Tostes, $26(158-159): 35-7$.

FRIEDMAN, N.R. e GADEN, E.D., 1970. Growth and Acid Production by Lactobacillus (L.) delbrueckie in a dialysis culture System. Biotech. Biogeng, 12, 961-974. "In: ACCOLAS, J.P. et al., 1977. Propiētes Acidificantes des Bactéries Lactiques Thermophiles en Relation avec la Fabrication du Yogurt. Le Lait, 561-562, 1-23".

GALESLOOT, Th. E. et al., 1958. Netherland Milk Dairy $\underline{\mathrm{J}}$., 12, 130. "In: TAMIME, A.Y. e DEETH, H.C., 1980. Yogurt: Techno logy and Biochemistry'. Journal of Food Protection, 43 , $939-977^{\prime \prime}$. 
GALESLOOT, Th.E. e HASSING, F., 1969. Dairy Sci. Abstr., 31 , 63. "In: TAMIME, A.Y. e DEETH, H.C., 1980. Yogurt: Technology and Biochemistry'. Journal of Food Protection, 43 , $939-977^{\prime \prime}$.

GIRGINOV, T.A., 1971. Dairy Sci. Abstr., 33, 195. "In: TAMIME, A.Y. e DEETH, H.C., 1980. Yogurt: Technology and Biochemis try'. Journal of Food Protection, 43, 939-977".

GRADHAGE, L. e THURELL, K.E., 1978. XX International Dairy Congress E. 1019. "In: TAMIME, A.Y. e DEETH, H.C., 1980. Yogurt: Technology and Biochemistry. Journal of Food protection, 43, 939-977".

GRIGOROV, M., 1966b. XVII International Dairy Congress, E/F 643. "In: TAMIME, A.Y, e DEETH, H.C., 1980. Yogurt: Techno logy and Biochemistry'. Journal of Food Protection, 43 , $939-977^{\prime \prime}$.

GRIGOROV, M., 1966C. XVII International Dairy Congress, E/F 649. "In: TAMIME, A.Y, e DEETH, H.C., 1980. Yogurt: Techno logy and Biochemistry'. Journal of Food Protection, 43 , $939-977^{\prime \prime}$.

GROZDOVA, G.N., 1971. Dairy Sci. Abstr., 33, 453. "In: TAMIME, A.Y, e DEETH, H.C., 1980. Yogurt: Technology and Biochemis try'. Journal of Food Protection, 43, 939-977".

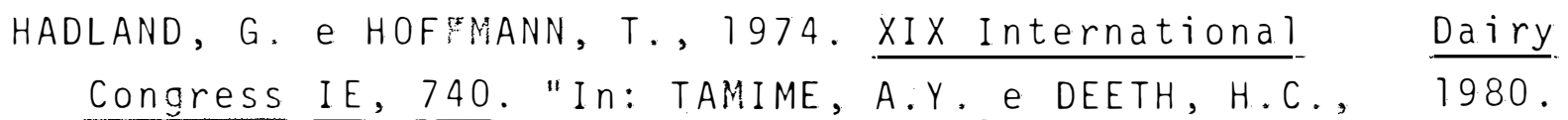
Yogurt: Technology and Biochemistry'. Journal of Food Protection, 43, 939-977". 
HAMDAN, I.Y. et al., 1971b. ‥ Dairy Sci., 54, 1080. "In: TAMIME, A.Y. e DEETH, H.C., 1980. Yogurt: Technology and Biochemistry'. Journal of Food Protection, 43, 939-977".

HAMMOND, L.A., 1972. Seminaron Recombined Dairy Products Session 3, page 58-64, CSIRO, Austrälia. "In: TAMIME, A.Y. e DEETH, H.C., 1980. Yogurt: Technology and Biochemistry'. Journal of Food Protection, 43, 939-977".

HELFERICH, W. e WESTMOFF, D., 1980. All About Yogurt. PrenticeHall, Inc., Englewood Cheffs, N. Jersey, 145p.

HUMPHREYS, C.L. e PLUNKETT, M., 1969. Yogurt: A review of its Manufacture. Dairy Sci. Abstr., 31 (11), 607-22.

IYENGAR, M.K.K. et al., 1967. Indian ‥ Dairy Sci., 20, 8. "In: TAMIME, A.Y; e DEETH, H.C., 1980. Yogurt: Technology and Biochemistry'. Journal of Food Protection, 43, 939 $977^{\prime \prime}$.

JENNESS, R. e PATTON, S., 1969. Principles of Dairy Chemistry. New York, John wiley e Sons. "In: HUMPHREYS, C.L. e PLUN KETT, M., 1969. Yogurt: A Review of its Manufacture. Dairy sci. Abstr., $31(11), 607-22^{\prime \prime}$.

KALAB, M. et al., 1976. Milchwissenschaft 31, 402. "In: TAMIME, A.Y. e DEETH, H.C., 1980. Yogurt: Technology arid Bio chemistry'. Journal of Food Protection, 43, 939-977".

KILARA, A. e SHAHANI, K.M., 1978. Lactic Fermentation of Dairy Foods and their Biological Significance. Journal of Dairy Science, 61, 1973. 
KISZA, J. e ROTKIEWICZ, W., 1967. Milchwissenschaft, 22, 627. "In: HUMPHREYS, C.L. e PLUNKETT, M., 1969. Yogurt: A Review of Its Manufacture. Dairy Sci. Abstr., 31 (11), 607-22".

KURMANN, J.A., 1977. Os Fatores Biológicos e Técnicos da Fabricação do Iogurte. Anais do IV Congresso Nacional de Laticinios, 74-84.

LARSON, B.L. e ROLLERI, G.D., 1955. ‥ Dairy Sci., 38, 351. "In: TAMIME, A.Y. e DEETH, H.C., 1980. Yogurt: Technology and Biochemistry'. Journal of Food Protection, 43, 939 $977^{\prime \prime}$.

$\therefore$ JYD, D.T., 1971. New developments in starter technology. Dairy Sci. Abstr. 33 (6), 411-416. "In: MARTINS, J. E. P., 1981. Controle de Culturas Láticas e seu uso adequado. In $\underline{s}$ truções Técnicas do Instituto de Tecnologia de Alimentos, n! 17".

JEKING, R. e PIRET, E.L., 1959. A Kinetic Study of the -actic Acid Fermentation. Batch Process at Controlled pH. 1. Biochem. Microbiol. Techn. Eng., I, 393-442. "In: AccoLAS, J.P. et al., 1977. Propiétes. Acidificantes des Bactéries Lactique Thermoplhiles en Relation avec la Fabrication du yogurt. Le Lait, 561-562, 1-23".

LUNDSTEDT, E., 1974. Amer. Dairy Rev., 36, 38A. "In: TAMIME, A.Y; e DEETH, H.C., 1980. Yogurt: Technology and Biochemis try'. Journal of Food Protection, 43, 939-977".

MARTENS, R., 1972. Dairy Sci. Abstr., 34, 602. "In: TAMIME, A.Y, e DEETH, H.C., 1980. Yogurt: Technology and Biochemis try'. journal of Food Protection. 43, 939-977". 
MARTINS, J.F.P., 1981. Controle de Culturas Läticas e seu Uso Adequado. Instruçöes Técnicas do Instituto de Tecnologia de Alimentos, no 17 .

MILLER, I. et al., 1964. Milchwissenschaft, 19, 18. "In: TAMI ME, A.Y. e DEETH, H.C., 1980. Yogurt: Techonology and Biochemistry'. Journal of Food Protection, 43, 939-977".

NIELSEN, J.P., 1974. XIX International Dairy Congress IE, 736. "In: TAMIME, A.Y. e DEETH, H.C., 1980. Yogurt: Techno logy and Biochemistry'. Journal of Food Protection, 43, $939-977^{\prime \prime}$.

NIKOLOV, N.M. e CHERNEV, P., 1967. Dairy Sci. Abstr., 29, 17. "In: TAMIME, A.Y. e DEETH, H.C., 1980. Yogurt: Technology and Biochemistry ${ }^{7}$. Journal of Food Protection, 43, 939 $977^{\prime \prime}$.

PETTE, J.W., 1950. Symbiosis and Antibiosis in Mixed Cultures of $L$. bulgaricus and $S$. thermophillus. Neth. Milk $\frac{\text { Dairy }}{1980}$ J.. 4 , 197-208. "In: TAMIME, A.Y. e DEETH, H.C., 1980. Yogurt: Technology and Biochemistry'. Journal of Food Protection, 43, 939-977".

PETTER, J.W. e LOLKEMA, M., 1951b. Factors Influencing the Proportion of Streptococci and Lactobacilli in a Yogurt Culture. Neth. Milk Dairy $\underline{J}, \underline{5}, 14-26$.

PRODANSKI, P., 1967. Milchwissenschaft 22, 167. "In: TAMIME, A.Y, e DEETH, H.C., 1980. Yogurt: Technology and Biochemis try'. Journal of Food Protection, 43, 939-977". 
PUHAN, Z, et al., 1974. XIX International Dairy Congress IE, 451. "In: TAMIME, A.Y, e DEETH, H.C., 1980. Yogurt: Techno logy and Biochemistry'. Journal of Food Protection, 43 , $939-977^{\prime \prime}$.

PULAY, G. e KRASZ, A., 1974. XIX International Dairy Congress. IE, 413. "In: TAMIME, A.Y. e DEETH, H.C., 1980. Yogurt: Technology and Biochemistry'. Journal of Food Protection, $43,939-977^{\prime \prime}$.

RASIC, J. e PANIC, B., 1961. Arch. poljopr. Nauk. 14. 94 (DSA 23(3326)). "In: HUMPHREYS, C.L. e PLUNKETT, M., 1969. Yogurt: A Review of Its Manufacture. Dairy Sci. Abstr., 31 (11), 607-22".

RASIC, J. e PANIC, B., 1963. Dairy Inds., 28, 35. "In: HUM PHREYS, C.L. e PLUNKETT, M., 1969. Yogurt: A Review of Its Manufacture. Dairy Sci. Abstr., 3i (17), 607-22".

REICHART, 0., 1978. Kinetic Analysis of Batch Fermentations of Yogurt. Acta. Alimentaria, $\underline{7}(4), 309-21$.

ROBINSON, R.K. e TAMIME, A.Y., 1976. Quality Appraisal of Yogurt. Journal of the Society of Dairy Techn. 29 (3), 148 -55 .

SALJI, J.P. e ISMAIL, A.A., 1983. Effect of initial acidity of plain yogurt on acidity changes during refrigerated sto rage. Journal of Food Science, 48(1), 258-259.

SAWYER, W.H., 1969. 3. Dairy Sci., 52, 1347. "In: TAMIME, A. Y. e DEETH, H.C., 1980. Yogurt: Technology and Biochemis try'. Journal of Food Protection, 43, 939-977". 
SCHONHERR, W., 1959. Manual Prático de Analisis de Leche. Edi torial Acribia, Zaragoza, $239 \mathrm{p}$.

SELLARS, R.L. e BABEL, F.J., 1970. Cultures for the Manufactu re of Dairy Products's Christensen Hansen's Lab. Inc. Wisconsin, pp. 46-49.

SHANKAR, P.A. et al., 1977. ‥ Soc. Dairy Technol., 30, 28. "In: TAMIME, A.Y. e DEETH, H.C., 1980. Yogurt: Technology and Biochemistry'. Journal of Food Protection, 43, 939 $977^{\prime \prime}$.

SHANKAR, P.A. E DAVIES, F.L., 1978. XX International $\frac{\text { Dairy }}{\text { DEETH, H.C. }}$ Yogurt: Technology and Biochemistryl. Journal of Food Protection, 43, 939-977".

SiEgenthaleR, E.H. e RITTER, P., 1964a. Fermented Milks'idf. Annual Bulletin Part III, page 54-59, Bruxelles, Belgium. "In: TAMIME, A.Y. e DEETH, H.C., 1980. Yogurt: Technology and Biochemistry'. Journal of Food Protection, 43,939 $977^{\prime \prime}$.

SPECK, M.L., 1977. ‥ Food Prot. 40, 863. "In: TAMIME, A.Y.e DEETH, H.C., 1980. Yogurt: Technology and Biochemistry'. Journal of Food Protection, 43, 939-977".

SPREER', E., 1975. Lactologia Industrial, Zaragoza, Editorial Acribia, $458 \mathrm{p}$.

STADHOUDER, J. e HASSING, F. 1974. Dairy Sci. Abstr., 36, 448. "In: TAMIME, A.Y. e DEETH, H.C., 1980. Yogurt: Techno logy and Biochemistry'. Journal of Food Protection, 43, $939-977^{\prime \prime}$. 
STOCKLIN, P., 1969. Cultured Dairy Prod. 4, 6. "In: TAMIME, A.Y. E DEETH, H.C., 1980. Yogurt: Technology and Biochemis try'. Journal of Food Protection, 43, 939-977".

STOLK, K., 1955. Netherland Milk Dairy ‥, 9, 37. "In: TAMIME, A.Y. e DEETH, H.C., 1980. Yogurt: Technology and Biochemis try ${ }^{1}$. Journal of Food Protection, 43, 939-977".

STORGARDS, T., 1964. Fermented Milk's. IDF Annual Bulletin Part III, page 65-75, Bruxeles, Belgium. "In: TAMIME, A.Y. e DEETH, H.C., 1980. Yogurt: Technology and Biochemistry'. Journal of Food Protection, 43, 939-977".

SULC, J., 1960a. "In: hUMPhREYS, C.L. e PLUNKETT, M., 1969. Yogurt: A Review of Its Manufacture. Dairy Sci. Abstr., 31 (11), 607-22".

SULC, J., 1963. Enrichment of Yogurt with Vitamin C. Tech. Publ. Stredisko. Protavinar Prumns1u., 139, 231-236. "In: TERRA, N.N. et al., 1977. Estudo do Iogurte Comercializado em Santa Maria, RS. Revista do Centro de Ciēncias Rurais, $\underline{7}(3), 275-287^{\prime \prime}$.

SURAZYNSKI, A. et al., 1975a. Produtos Läcteos Fermentados Y sus Propriedades Dietéticas: bioghurt y biogord. Industria Lechera, 642, 10-16.

TAMIME, A.Y. e DEETH, H.C., 1980. Yogurt: Technology and Biochemistry'. Journal of Food Protection, 43, 939-977".

TOBA, T. et al., 1983. Quantitative changes in sugars, espe cially oligosaccharides, during fermentation and storage of yogurt. J. Dairy Science, 66 (1), 17-20. 
VASSAL, L. e AUCLAIR, J., 1966. Variations de la Production d'Acide for les Bactéries du Yoghurt dans les Laits de Grand Mélange. XVII Congress Inst. Laitierie, E/F, 669 676. "In: ACCOLAS, J.P. et al., 1977. Propriétes Acidifi cantes des Bactéries Lactiques Thermophiles en Relation avec la Fabrication dy Yoghurt, Le Lait, 561-562, 1-32.

VIEIRA, S.D.A., 1981. A Utilização de Culturas Láticas na Indústria de Laticinios. Boletim do Leite, 267, janeiro.

WILCoX, G., 1971. Egg, Cheese \& Yogurt page 269, Food Proc. Rev. Noyes Data Corp., New Jersey, USA. "In: TAMIME, A.Y. e DEETH, H.C., 1980. Yogurt: Technology and Biochemistry'. Journal of Food Protection, 43, 939-977".

ZMARLICKI, S. et al., 1974. XIX International Dairy Congress. IE, 771. "In: TAMIME, A.Y. e DEETH, H.C., 1980. Yogurt: Technology and Biochemistry'. Journal of Food Protection, 43, $939-977 "$. 
7. APENDICE 
Tabela 1 - Caracteristicas principais do leite antes e após - tratamento térmico 65 c por 30 minutos.

$\mathrm{pH}$

7.00

6.90

6.80

6.80

6.90

6.80

Acidez titulāvel

$$
\begin{aligned}
& 0.17 \\
& 0.19 \\
& 0.14
\end{aligned}
$$$$
0.17
$$$$
0.21
$$$$
0.15
$$

Sólidos totais

13.96

14.10

14.96

15.21

12.35

13.29 


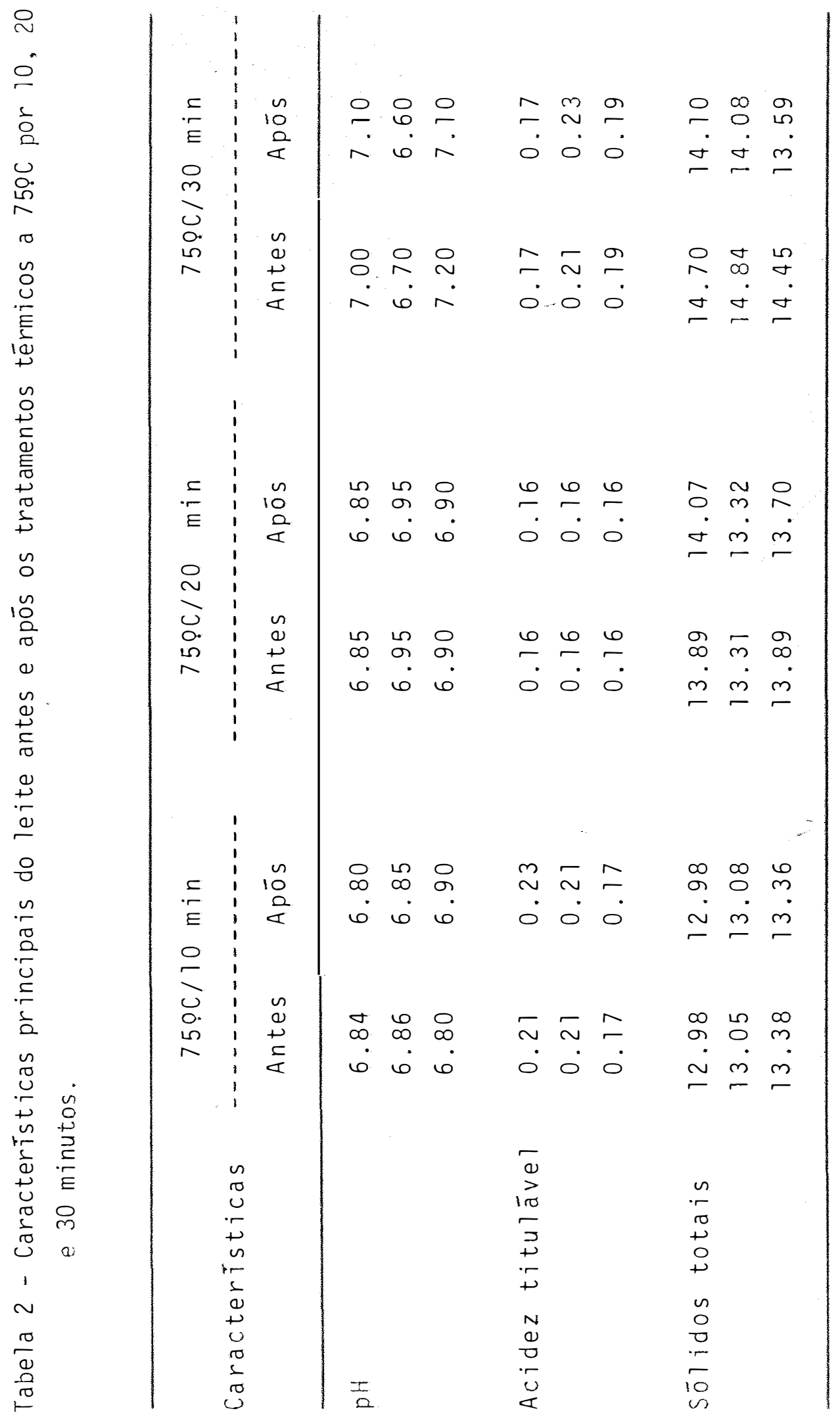




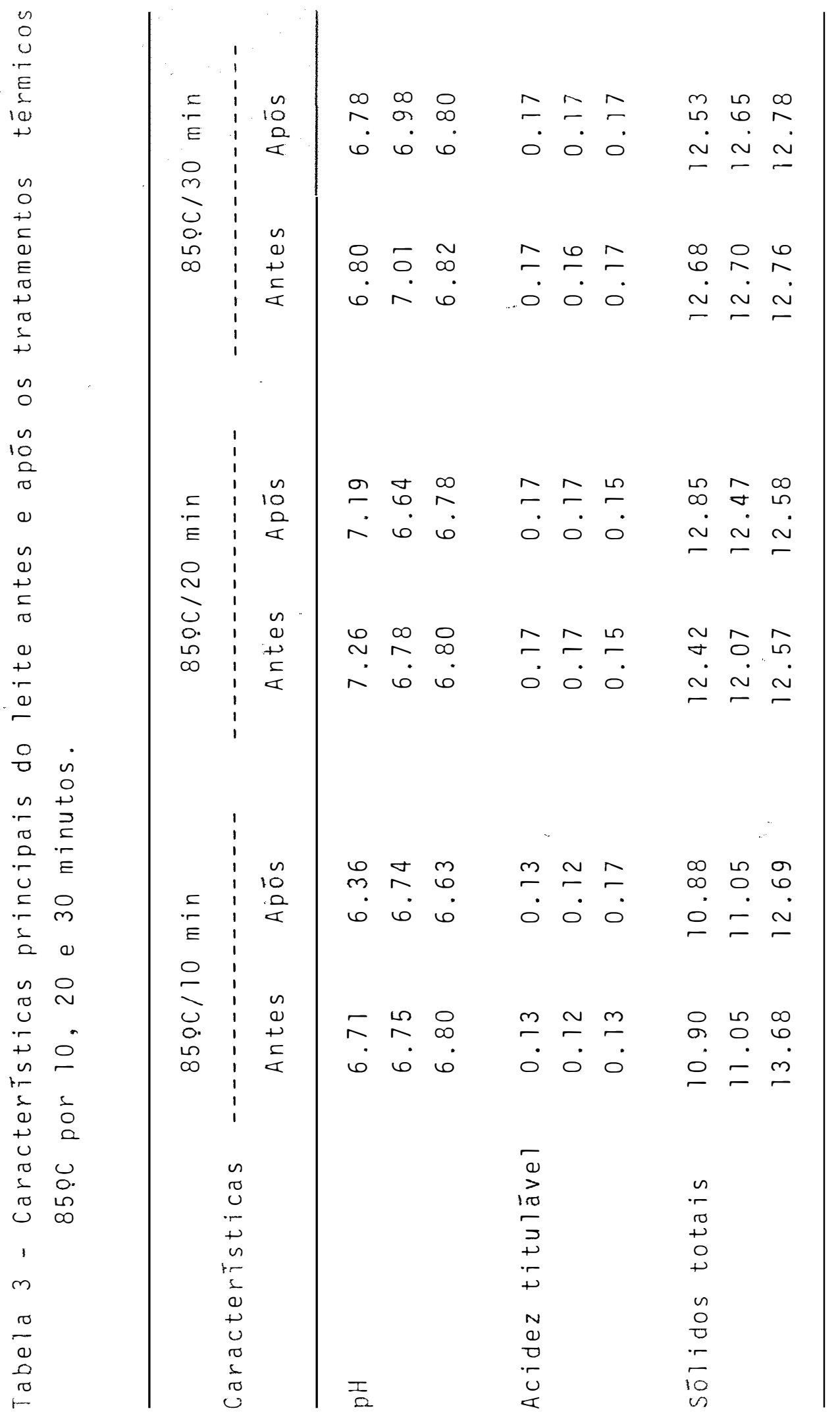


Tabela 4 - pH e acidéz titulàvel apōs tratamento térmic $650 \mathrm{C}$ por 30 minutos.

\begin{tabular}{|c|c|c|}
\hline $\begin{array}{c}\text { Tempo } \\
\text { (minutos) }\end{array}$ & $\mathrm{pH}$ & Acidez \\
\hline 0 & $\begin{array}{l}6.90 \\
6.50 \\
6.50\end{array}$ & $\begin{array}{l}0.19 \\
0.23 \\
0.19\end{array}$ \\
\hline 20 & $\begin{array}{l}6.85 \\
6.30 \\
6.25\end{array}$ & $\begin{array}{l}0.21 \\
0.23 \\
0.23\end{array}$ \\
\hline 40 & $\begin{array}{l}6.70 \\
6.25 \\
6.05\end{array}$ & $\begin{array}{l}0.23 \\
0.23 \\
0.26\end{array}$ \\
\hline 60 & $\begin{array}{l}6.50 \\
6.10 \\
5.80\end{array}$ & $\begin{array}{l}0.26 \\
0.24 \\
0.31\end{array}$ \\
\hline 80 & $\begin{array}{l}6.00 \\
5.95 \\
5.50\end{array}$ & $\begin{array}{l}0.33 \\
0.24 \\
0.35\end{array}$ \\
\hline 100 & $\begin{array}{l}5.20 \\
5.70 \\
5.00\end{array}$ & $\begin{array}{l}0.58 \\
0.30 \\
0.47\end{array}$ \\
\hline 120 & $\begin{array}{l}4.70 \\
5.35 \\
4.60\end{array}$ & $\begin{array}{l}0.66 \\
0.35 \\
0.53\end{array}$ \\
\hline 140 & $\begin{array}{l}4.50 \\
5.10 \\
4.40\end{array}$ & $\begin{array}{l}0.77 \\
0.42 \\
0.66\end{array}$ \\
\hline 160 & $\begin{array}{l}4.25 \\
4.95 \\
4.30\end{array}$ & $\begin{array}{l}0.88 \\
0.49 \\
0.77\end{array}$ \\
\hline 180 & $\begin{array}{l}4.20 \\
4.75 \\
4.20\end{array}$ & $\begin{array}{l}0.93 \\
0.53 \\
0.88\end{array}$ \\
\hline
\end{tabular}

Temperatura de inculação: 4200 . 
Tabela 5 - pH e acidez titulävel após tratamentos térmicos a $750 \mathrm{C}$ por 10,20 e 30 minutos.

\begin{tabular}{|c|c|c|c|c|c|c|}
\hline $\begin{array}{c}\text { Tempo } \\
\text { (minutos) }\end{array}$ & $\begin{array}{c}750 \mathrm{C} / \\
\mathrm{pH}^{---}\end{array}$ & $\begin{array}{l}\text { Omin } \\
\text { Acidez }\end{array}$ & $\begin{array}{c}75 \mathrm{OC} / \\
\mathrm{pH}\end{array}$ & $20 \mathrm{~min}$ & $\begin{array}{c}75 \mathrm{OC} / \\
\mathrm{pH}\end{array}$ & $\begin{array}{l}30 \mathrm{~min} \\
\text { Acidez }\end{array}$ \\
\hline 0 & $\begin{array}{l}6.50 \\
6.80 \\
6.70\end{array}$ & $\begin{array}{l}0.27 \\
0.27 \\
0.19\end{array}$ & $\begin{array}{l}6.70 \\
6.80 \\
6.95\end{array}$ & $\begin{array}{l}0.19 \\
0.19 \\
0.19\end{array}$ & $\begin{array}{l}6.95 \\
6.60 \\
7.15\end{array}$ & $\begin{array}{l}0.23 \\
0.26 \\
0.21\end{array}$ \\
\hline 20 & $\begin{array}{l}6.50 \\
6.80 \\
6.60\end{array}$ & $\begin{array}{l}0.27 \\
0.27 \\
0.27\end{array}$ & $\begin{array}{l}6.65 \\
6.75 \\
6.80\end{array}$ & $\begin{array}{l}0.21 \\
0.23 \\
0.21\end{array}$ & $\begin{array}{l}6.85 \\
6.55 \\
7.15\end{array}$ & $\begin{array}{l}0.23 \\
0.26 \\
0.23\end{array}$ \\
\hline 40 & $\begin{array}{l}6.30 \\
6.70 \\
6.40\end{array}$ & $\begin{array}{l}0.35 \\
0.30 \\
0.21\end{array}$ & $\begin{array}{l}6.60 \\
6.70 \\
6.70\end{array}$ & $\begin{array}{l}0.23 \\
0.26 \\
0.24\end{array}$ & $\begin{array}{l}6.85 \\
6.50 \\
7.15\end{array}$ & $\begin{array}{l}0.23 \\
0.28 \\
0.23\end{array}$ \\
\hline 60 & $\begin{array}{l}6.00 \\
6.50 \\
6.30\end{array}$ & $\begin{array}{l}0.35 \\
0.32 \\
0.24\end{array}$ & $\begin{array}{l}6.50 \\
6.50 \\
6.50\end{array}$ & $\begin{array}{l}0.24 \\
0.27 \\
0.28\end{array}$ & $\begin{array}{l}6.70 \\
6.50 \\
7.75\end{array}$ & $\begin{array}{l}0.24 \\
0.30 \\
0.24\end{array}$ \\
\hline 80 & $\begin{array}{l}5.30 \\
6.10 \\
5.90\end{array}$ & $\begin{array}{l}0.44 \\
0.35 \\
0.35\end{array}$ & $\begin{array}{l}6.50 \\
6.25 \\
6.45\end{array}$ & $\begin{array}{l}0.26 \\
0.32 \\
0.28\end{array}$ & $\begin{array}{l}6.50 \\
6.40 \\
7.10\end{array}$ & $\begin{array}{l}0.26 \\
0.30 \\
0.24\end{array}$ \\
\hline 100 & $\begin{array}{l}5.70 \\
5.90 \\
5.70\end{array}$ & $\begin{array}{l}0.66 \\
0.46 \\
0.40\end{array}$ & $\begin{array}{l}6.20 \\
5.85 \\
6.15\end{array}$ & $\begin{array}{l}0.35 \\
0.40 \\
0.35\end{array}$ & $\begin{array}{l}6.35 \\
6.45 \\
6.90\end{array}$ & $\begin{array}{l}0.32 \\
0.39 \\
0.28\end{array}$ \\
\hline 120 & $\begin{array}{l}5.00 \\
5.70 \\
5.20\end{array}$ & $\begin{array}{l}0.75 \\
0.60 \\
0.53\end{array}$ & $\begin{array}{l}5.85 \\
5.45 \\
6.00\end{array}$ & $\begin{array}{l}0.40 \\
0.56 \\
0.39\end{array}$ & $\begin{array}{l}6.10 \\
6.25 \\
6.70\end{array}$ & $\begin{array}{l}0.35 \\
0.49 \\
0.35\end{array}$ \\
\hline 140 & $\begin{array}{l}4.80 \\
4.80 \\
4.90\end{array}$ & $\begin{array}{l}0.82 \\
0.71 \\
0.58\end{array}$ & $\begin{array}{l}5.62 \\
5.10 \\
5.60\end{array}$ & $\begin{array}{l}0.49 \\
0.66 \\
0.49\end{array}$ & $\begin{array}{l}5.80 \\
5.70 \\
6.30\end{array}$ & $\begin{array}{l}0.49 \\
0.62 \\
0.42\end{array}$ \\
\hline 160 & $\begin{array}{l}4.70 \\
4.60 \\
4.60\end{array}$ & $\begin{array}{l}0.89 \\
0.71 \\
0.71\end{array}$ & $\begin{array}{l}5.40 \\
5.85 \\
5.25\end{array}$ & $\begin{array}{l}0.62 \\
0.71 \\
0.65\end{array}$ & $\begin{array}{l}5.50 \\
5.20 \\
6.10\end{array}$ & $\begin{array}{l}0.60 \\
0.76 \\
0.46\end{array}$ \\
\hline 180 & $\begin{array}{l}4.50 \\
4.50 \\
4.50\end{array}$ & $\begin{array}{l}0.92 \\
0.81 \\
0.85\end{array}$ & $\begin{array}{l}5.10 \\
4.65 \\
4.95\end{array}$ & $\begin{array}{l}0.78 \\
0.72 \\
0.67\end{array}$ & $\begin{array}{l}5.20 \\
4.80 \\
5.70\end{array}$ & $\begin{array}{l}0.67 \\
0.88 \\
0.58\end{array}$ \\
\hline
\end{tabular}

Temperatura de incubação: $420 \mathrm{C}$. 
Tabela 6 - pH e acidez titulävel apös tratamentos térmicos a $850 \mathrm{C}$ por 10,20 e 30 minutos.

\begin{tabular}{|c|c|c|c|c|c|c|}
\hline \multirow{2}{*}{$\begin{array}{c}\text { Tempo } \\
\text { (minutos) }\end{array}$} & \multicolumn{2}{|c|}{$850 \mathrm{c} / 10 \mathrm{~min}$} & \multicolumn{2}{|c|}{$850 \mathrm{c} / 20 \mathrm{~min}$} & \multicolumn{2}{|c|}{$850 \mathrm{C} / 30 \mathrm{~min}$} \\
\hline & $\mathrm{pH}$ & Acide $z$ & $\mathrm{pH}$ & Acidez & $\mathrm{pH}$ & Acidez \\
\hline 0 & $\begin{array}{l}6.63 \\
6.68 \\
6.77\end{array}$ & $\begin{array}{l}0.17 \\
0.17 \\
0.17\end{array}$ & $\begin{array}{l}7.01 \\
6.34 \\
6.30\end{array}$ & $\begin{array}{l}0.21 \\
0.16 \\
0.23\end{array}$ & $\begin{array}{l}6.90 \\
6.95 \\
6.10\end{array}$ & $\begin{array}{l}0.23 \\
0.23 \\
0.21\end{array}$ \\
\hline 20 & $\begin{array}{l}6.55 \\
6.67 \\
6.54\end{array}$ & $\begin{array}{l}0.19 \\
0.17 \\
0.17\end{array}$ & $\begin{array}{l}6.71 \\
6.04 \\
6.04\end{array}$ & $\begin{array}{l}0.25 \\
0.18 \\
0.25\end{array}$ & $\begin{array}{l}6.90 \\
6.51 \\
6.30\end{array}$ & $\begin{array}{l}0.23 \\
0.25 \\
0.23\end{array}$ \\
\hline 40 & $\begin{array}{l}6.29 \\
6.57 \\
6.31\end{array}$ & $\begin{array}{l}0.19 \\
0.19 \\
0.21\end{array}$ & $\begin{array}{l}5.89 \\
5.85 \\
5.70\end{array}$ & $\begin{array}{l}0.25 \\
0.21 \\
0.30\end{array}$ & $\begin{array}{l}6.70 \\
6.30 \\
6.50\end{array}$ & $\begin{array}{l}0.25 \\
0.32 \\
0.27\end{array}$ \\
\hline 60 & $\begin{array}{l}5.90 \\
6.05 \\
5.83\end{array}$ & $\begin{array}{l}0.23 \\
0.24 \\
0.28\end{array}$ & $\begin{array}{l}5.38 \\
5.70 \\
5.38\end{array}$ & $\begin{array}{l}0.28 \\
0.25 \\
0.46\end{array}$ & $\begin{array}{l}6.50 \\
6.18 \\
6.40\end{array}$ & $\begin{array}{l}0.32 \\
0.34 \\
0.28\end{array}$ \\
\hline 80 & $\begin{array}{l}5.41 \\
6.30 \\
5.66\end{array}$ & $\begin{array}{l}0.26 \\
0.31 \\
0.31\end{array}$ & $\begin{array}{l}5.01 \\
5.45 \\
4.97\end{array}$ & $\begin{array}{l}0.37 \\
0.32 \\
0.55\end{array}$ & $\begin{array}{l}6.30 \\
5.89 \\
6.30\end{array}$ & $\begin{array}{l}0.39 \\
0.30 \\
0.30\end{array}$ \\
\hline 100 & $\begin{array}{l}4.94 \\
5.52 \\
5.04\end{array}$ & $\begin{array}{l}0.33 \\
0.40 \\
0.44\end{array}$ & $\begin{array}{l}4.83 \\
5.20 \\
4.85\end{array}$ & $\begin{array}{l}0.48 \\
0.41 \\
0.66\end{array}$ & $\begin{array}{l}5.70 \\
5.68 \\
6.00\end{array}$ & $\begin{array}{l}0.50 \\
0.50 \\
0.37\end{array}$ \\
\hline 120 & $\begin{array}{l}4.47 \\
4.98 \\
4.80\end{array}$ & $\begin{array}{l}0.44 \\
0.50 \\
0.61\end{array}$ & $\begin{array}{l}4.19 \\
5.02 \\
4.44\end{array}$ & $\begin{array}{l}0.53 \\
0.41 \\
0.75\end{array}$ & $\begin{array}{l}5.40 \\
5.25 \\
5.30\end{array}$ & $\begin{array}{l}0.62 \\
0.64 \\
0.46\end{array}$ \\
\hline 140 & $\begin{array}{l}4.68 \\
4.45 \\
4.72\end{array}$ & $\begin{array}{l}0.52 \\
0.59 \\
0.70\end{array}$ & $\begin{array}{l}3.94 \\
4.75 \\
4.46\end{array}$ & $\begin{array}{l}0.62 \\
0.43 \\
0.76\end{array}$ & $\begin{array}{l}5.10 \\
4.97 \\
5.20\end{array}$ & $\begin{array}{l}0.66 \\
0.78 \\
0.57\end{array}$ \\
\hline 160 & $\begin{array}{l}4.56 \\
4.23 \\
4.67\end{array}$ & $\begin{array}{l}0.59 \\
0.61 \\
0.70\end{array}$ & $\begin{array}{l}3.81 \\
4.60 \\
4.04\end{array}$ & $\begin{array}{l}0.73 \\
0.44 \\
0.82\end{array}$ & $\begin{array}{l}4.90 \\
4.80 \\
5.00\end{array}$ & $\begin{array}{l}0.66 \\
0.82 \\
0.59\end{array}$ \\
\hline 180 & $\begin{array}{l}4.40 \\
4.30 \\
4.56\end{array}$ & $\begin{array}{l}0.61 \\
0.68 \\
0.70\end{array}$ & $\begin{array}{l}3.55 \\
4.53 \\
3.89\end{array}$ & $\begin{array}{l}0.78 \\
0.57 \\
0.87\end{array}$ & $\begin{array}{l}4.80 \\
4.66 \\
4.80\end{array}$ & $\begin{array}{l}0.85 \\
0.89 \\
0.67\end{array}$ \\
\hline
\end{tabular}

Temperatura de incubação: 420 C. 
Tabela 7 - pHe acidez titulävel apös tratamento térmico a $750 \mathrm{C}$ por 30 minutos e temperaturas de incubação $320 \mathrm{C}$ e $370 \mathrm{C}$.

\begin{tabular}{|c|c|c|c|c|}
\hline \multirow{2}{*}{$\begin{array}{c}\text { Tempo } \\
\frac{(\text { minutos })}{0}\end{array}$} & \multicolumn{2}{|c|}{$\begin{array}{c}320 \mathrm{C} \\
\mathrm{pH} \quad \text { Acidez }\end{array}$} & \multicolumn{2}{|c|}{$\begin{array}{c}370 \mathrm{C} \\
\mathrm{pH} \quad \text { Acidez }\end{array}$} \\
\hline & 6.70 & 0.19 & 6.70 & 0.17 \\
\hline & 6.70 & 0.17 & 6.60 & 0.77 \\
\hline & 6.40 & 0.19 & 6.40 & 0.19 \\
\hline \multirow[t]{3}{*}{20} & -6.65 & 0.19 & 6.65 & 0.21 \\
\hline & 6.60 & 0.21 & 6.50 & 0.21 \\
\hline & 6.40 & 0.21 & 6.40 & 0.21 \\
\hline 40 & 6.50 & 0.22 & 6.55 & 0.22 \\
\hline \multirow[t]{2}{*}{. } & 6.75 & 0.22 & 6.60 & 0.22 \\
\hline & 6.25 & 0.21 & 6.25 & 0.24 \\
\hline \multirow[t]{3}{*}{60} & 6.40 & 0.24 & 6.40 & 0.22 \\
\hline & 6.50 & 0.26 & 5.90 & 0.24 \\
\hline & 6.15 & 0.22 & 6.00 & 0.31 \\
\hline \multirow[t]{3}{*}{80} & 6.30 & 0.26 & 5.80 & 0.29 \\
\hline & 6.30 & 0.28 & 5.40 & 0.26 \\
\hline & 5.98 & 0.22 & 5.40 & 0.45 \\
\hline \multirow[t]{3}{*}{100} & 6.10 & 0.31 & 3.75 & 0.35 \\
\hline & 5.90 & 0.28 & 5.50 & 0.35 \\
\hline & 5.90 & 0.22 & 4.60 & 0.58 \\
\hline \multirow[t]{3}{*}{120} & 6.10 & 0.33 & 5.30 & 0.42 \\
\hline & 5.92 & 0.22 & 5.30 & 0.45 \\
\hline & 5.73 & 0.24 & 5.20 & 0.51 \\
\hline
\end{tabular}


Tabela 7 - Continuação.

\begin{tabular}{|c|c|c|c|c|}
\hline \multirow{2}{*}{$\begin{array}{c}\text { Tempo } \\
\text { (minutos) }\end{array}$} & \multicolumn{2}{|c|}{3200} & \multicolumn{2}{|c|}{$379 \mathrm{C}$} \\
\hline & $\mathrm{pH}$ & Acidez & $\mathrm{pH}$ & Acidez \\
\hline \multirow[t]{3}{*}{140} & 5.60 & 0.38 & 5.00 & 0.49 \\
\hline & 5.85 & 0.28 & 5.28 & 0.51 \\
\hline & 5.65 & 0.29 & 4.60 & 0.65 \\
\hline \multirow[t]{3}{*}{160} & 5.00 & 0.44 & 4.50 & 0.58 \\
\hline & 5.80 & 0.31 & 4.53 & 0.58 \\
\hline & 5.52 & 0.35 & 4.30 & 0.72 \\
\hline \multirow[t]{3}{*}{180} & 4.50 & 0.44 & 4.30 & 0.58 \\
\hline & 5.80 & 0.35 & 4.12 & 0.70 \\
\hline & 5.30 & 0.49 & 4.30 & 0.72 \\
\hline \multirow[t]{3}{*}{200} & 4.50 & 0.44 & 4.15 & 0.61 \\
\hline & 5.10 & 0.37 & 4.19 & 0.63 \\
\hline & 5.12 & 0.47 & 4.25 & 0.79 \\
\hline \multirow[t]{3}{*}{220} & 4.30 & 0.52 & 4.15 & 0.70 \\
\hline & 4.84 & 0.56 & 4.19 & 0.70 \\
\hline & 4.98 & 0.47 & 4.10 & 0.79 \\
\hline \multirow[t]{3}{*}{240} & 4.25 & 0.61 & - & - \\
\hline & 4.89 & 0.58 & - & - \\
\hline & 4.90 & 0.51 & - & - \\
\hline \multirow[t]{3}{*}{260} & 4.20 & 0.70 & - & - \\
\hline & 4.80 & 0.65 & - & - \\
\hline & 4.85 & 0.52 & - & - \\
\hline
\end{tabular}


Tabela 8-pH e acidez titulävel após tratamento térmico a 850 c por 30 minutos e temperatura de incubação $320 C^{\circ}$ e 370 .

\begin{tabular}{|c|c|c|c|c|}
\hline \multirow{2}{*}{$\begin{array}{c}\text { Tempo } \\
\frac{(m i n u t o s)}{0}\end{array}$} & \multicolumn{2}{|c|}{ PH ACidez } & \multicolumn{2}{|c|}{ pH $37 O C$} \\
\hline & 6.80 & 0.17 & 6.80 & 0.21 \\
\hline & 6.84 & 0.17 & 6.90 & 0.17 \\
\hline & 6.90 & 0.17 & 6.86 & 0.17 \\
\hline \multirow[t]{3}{*}{20} & 6.65 & 0.21 & 6.75 & 0.22 \\
\hline & 6.60 & 0.19 & 6.60 & 0.22 \\
\hline & 6.80 & 0.17 & 6.80 & 0.21 \\
\hline \multirow[t]{3}{*}{40} & 6.65 & 0.22 & 6.75 & 0.28 \\
\hline & 6.45 & 0.22 & 6.40 & 0.22 \\
\hline & 6.72 & 0.21 & 6.72 & 0.22 \\
\hline \multirow[t]{3}{*}{60} & 6.40 & 0.24 & 6.60 & 0.35 \\
\hline & 6.25 & 0.22 & 6.15 & 0.24 \\
\hline & 6.70 & 0.21 & 6.60 & 0.22 \\
\hline \multirow[t]{3}{*}{80} & 6.20 & 0.29 & 6.25 & 0.42 \\
\hline & 6.10 & 0.24 & 5.95 & 0.26 \\
\hline & 6.50 & 0.28 & 6.45 & 0.24 \\
\hline \multicolumn{5}{|l|}{. } \\
\hline \multirow[t]{3}{*}{100} & 6.15 & 0.33 & 5.90 & 0.49 \\
\hline & 5.95 & 0.28 & 5.65 & 0.28 \\
\hline & 6.38 & 0.28 & 6.00 & 0.28 \\
\hline \multirow[t]{3}{*}{120} & 5.85 & 0.45 & 5,75 & 0.56 \\
\hline & 5.80 & 0.40 & 5.38 & 0.35 \\
\hline & 6.30 & 0.31 & 5.80 & $0.3]$ \\
\hline
\end{tabular}


Tabela 8 - Continuação.

\begin{tabular}{|c|c|c|c|c|}
\hline \multirow{2}{*}{$\begin{array}{c}\text { Tempo } \\
\text { (minutos) } \\
140\end{array}$} & \multicolumn{2}{|c|}{ pH $\quad 320 \mathrm{C}$} & \multicolumn{2}{|c|}{$\begin{array}{c}370 \mathrm{C} \\
\mathrm{pH} \quad \text { Acidez }\end{array}$} \\
\hline & 5.65 & 0.49 & 5.50 & 0.61 \\
\hline & 5.73 & 0.40 & 4.98 & 0.38 \\
\hline & 6.70 & 0.33 & 5.63 & 0.35 \\
\hline \multirow[t]{3}{*}{160} & 5.65 & 0.52 & 5.25 & 0.61 \\
\hline & 5.55 & 0.40 & 4.90 & 0.40 \\
\hline & 5.90 & 0.37 & 5.35 & 0.38 \\
\hline \multirow[t]{3}{*}{180} & 5.65 & 0.52 & 4.80 & 0.67 \\
\hline & 5.38 & 0.52 & 4.87 & 0.52 \\
\hline & 5.75 & 0.38 & 5.15 & 0.56 \\
\hline \multirow[t]{3}{*}{200} & 5.40 & 0.58 & 4.60 & 0.70 \\
\hline & 5.10 & 0.58 & 4.85 & 0.67 \\
\hline & 5.53 & 0.47 & 4.90 & 0.59 \\
\hline \multirow[t]{3}{*}{220} & 5.20 & 0.59 & 4.45 & 0.75 \\
\hline & 4.95 & 0.72 & 4.70 & 0.56 \\
\hline & 5.25 & 0.52 & 4.85 & 0.70 \\
\hline \multirow[t]{3}{*}{240} & 5.00 & 0.65 & - & - \\
\hline & 4.95 & 0.70 & - & - \\
\hline & 4.95 & 0.58 & - & - \\
\hline \multirow[t]{3}{*}{260} & 4.90 & 0.70 & $\sim$ & - \\
\hline & 4.80 & 0.70 & - & - \\
\hline & 4.80 & 0.63 & - & - \\
\hline
\end{tabular}


81.

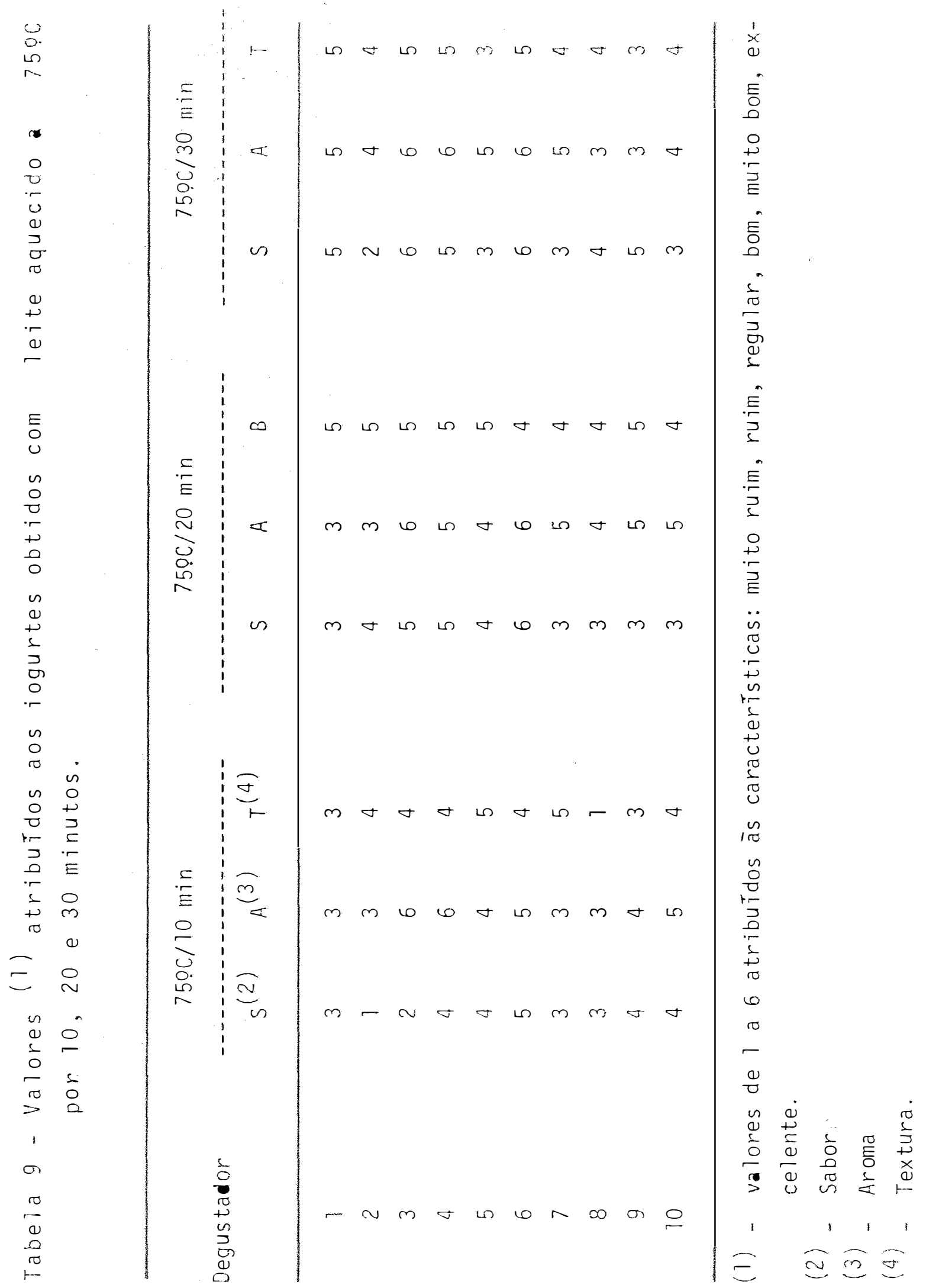


82.

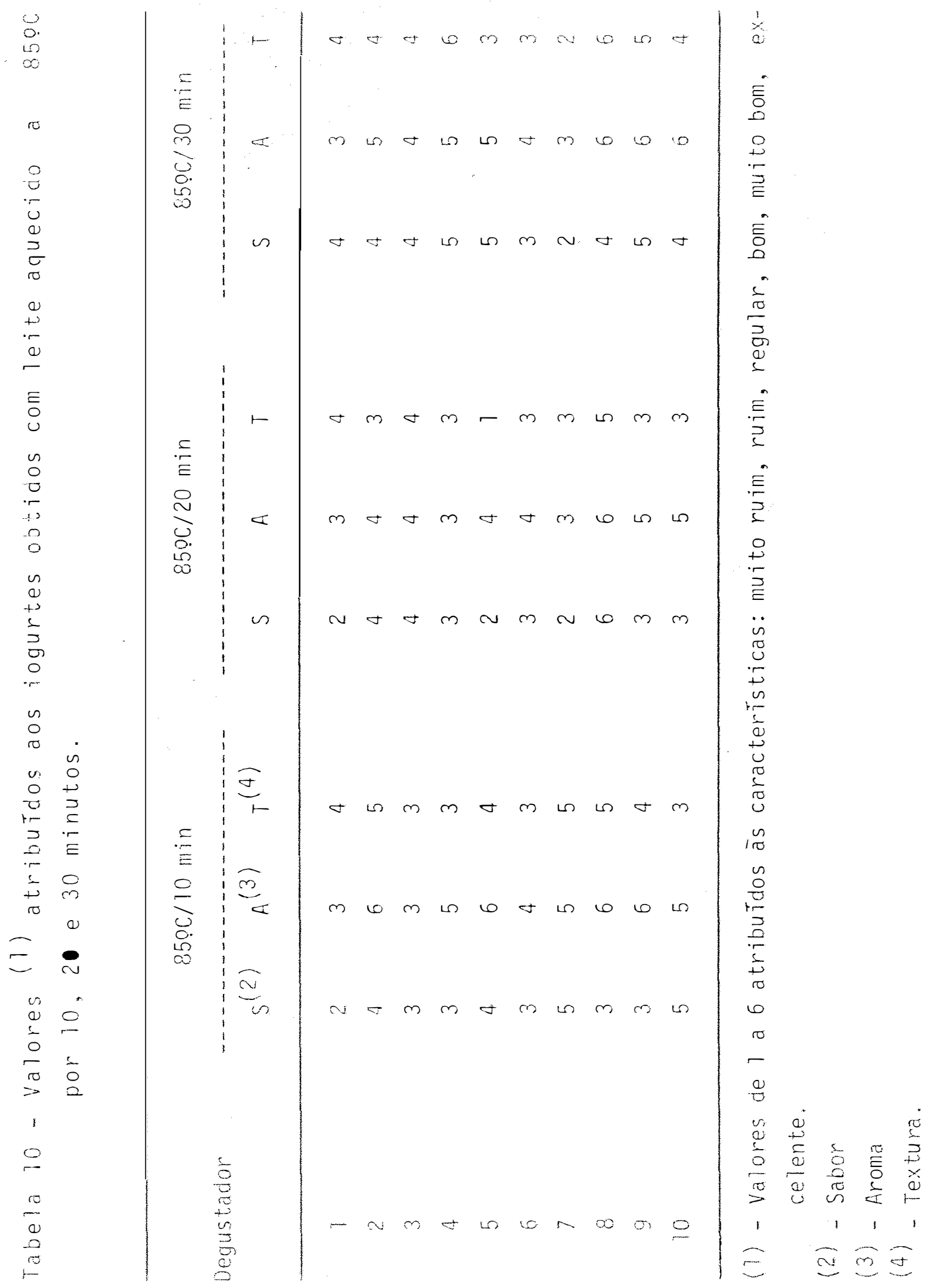




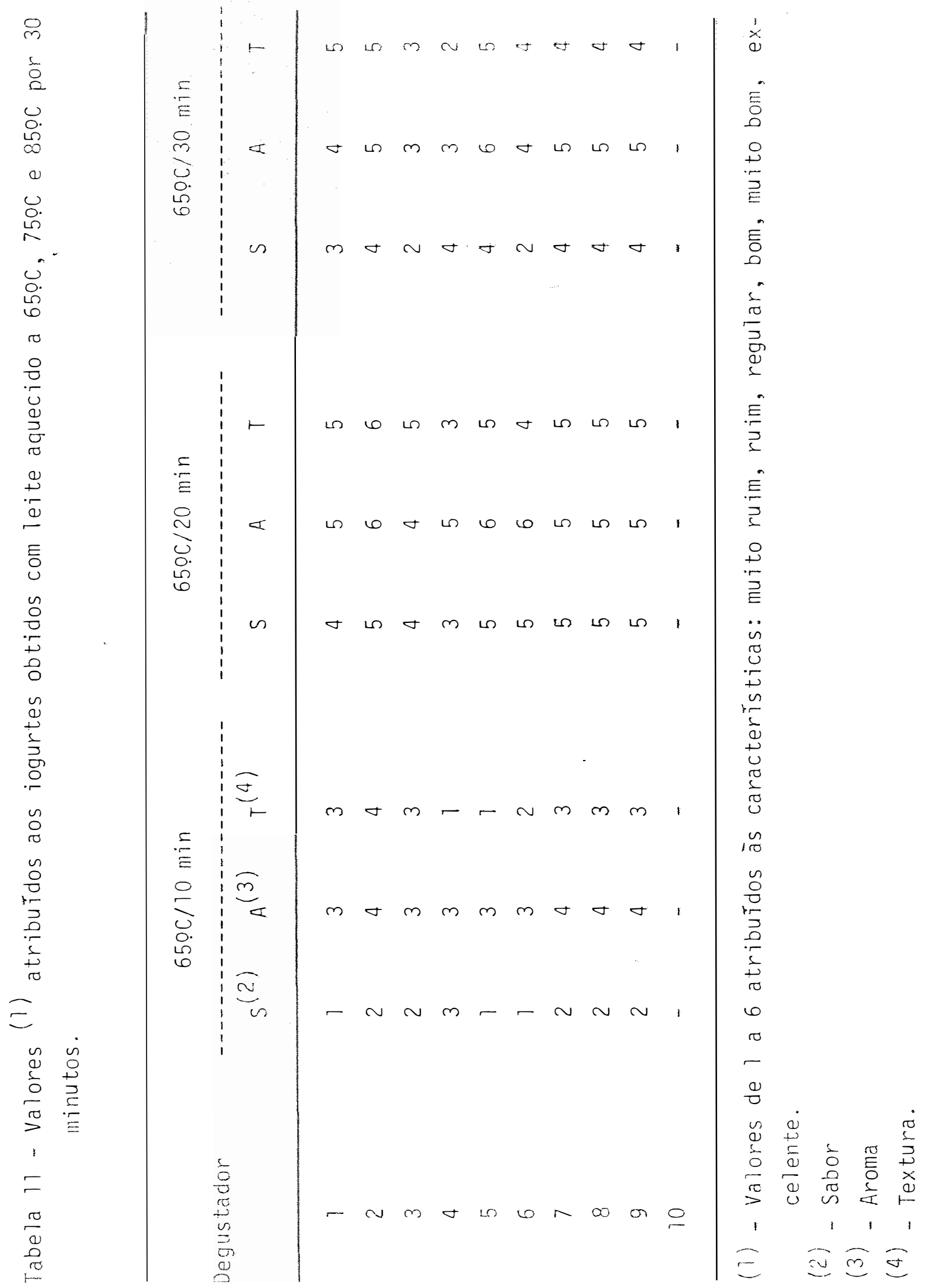

